\title{
Chemometrics Based Extraction of Polyphenolics from Fresh Tea Leaves and Processed Tea Showing In-Silico Docking and Anti- oxidative Theronostic Dietary Adjuvant in Alzheimer
}

\author{
Koushik Bhandari ${ }^{1}$, Rajeev K Singla ${ }^{2}$, Baishakhi De ${ }^{1}$, Bijoy Chandra Ghosh ${ }^{3}$, Prakash Katakam ${ }^{4}$, \\ Dilip Kumar Khushwaha ${ }^{3}$, Rohit Gundamaraju ${ }^{5}$, Gargi Sen ${ }^{6}$, Gargi Saha ${ }^{7}$, Anirban Mitra ${ }^{8}$, Analava \\ Mitra $^{1^{*}}$ \\ ${ }^{1}$ School of Medical Science \& Technology,IIT Kharagpur-721302, India \\ ${ }^{2}$ Division of Biotechnology, Netaji Subhas Institute of Technology, Dwarka, New Delhi, 110078, India \\ ${ }^{3}$ Tea Engineering Research Centre, Department of Agricultural and Food Engineering, IIT Kharagpur-721302, India \\ ${ }^{4}$ Faculty of Pharmacy, University of Zawia, Az-Zawia, Libya \\ ${ }^{5}$ Department of Medical Microbiology, Faculty of Medicine, University of Malaya, Kuala Lumpur 50603, Malaysia \\ ${ }^{6}$ Tea Board of India, Kolkata-700001, India \\ ${ }^{7}$ National Tea Research Foundation, Tea Tea Board of India, Kolkata-700001, India
}

${ }^{8}$ Department of CSE, V.I.T.A.M, Berhampur, Odisha, India

\begin{abstract}
Address for
Correspondance Analava Mitra, analavamitra@g $\underline{\text { mail.com }}$

Keywords

Chemometrics;

Tea

polyphenolics;

Antioxidant;

GRIP docking

studies;

Alzheimer.

ABSTRACT: Aim of the study is to chemometrically optimize the extraction procedure of tea polyphenolics, evaluate antioxidant potentials of fresh tea leaves and made tea grown in the non-traditional tea zone of IIT Kharagpur by in vitro assays, in silico docking studies and in vitro AChE inhibitory assays. Total tea polyphenolics, flavonoids and volatile contents of aqueous and methanolic extracts of fresh tea leaves and made tea were estimated by UV, HPLC and GC-MS analysis. The extraction process parameters were optimized by central composite design of chemometrics to maximize polyphenol yield. Antioxidant properties were studied by in vitro DPPH radical scavenging, FRAP, ABTS and Dot Blot Assay. In silico GRIP docking studies were done to evaluate the effectivity of tea catechins as antioxidants against the targeted proteins. In vitro AChE inhibitory assay was done to see its anti-Alzheimer effect. Basing on desirability function, $3.75 \pm 0.04 \mathrm{~g}$ of sample weight and $207.32 \pm 0.01 \mathrm{~mL}$ of methanol of TV fresh leaf varieties gave percent yield of poly phenols in range of $31.35 \pm 2.78-25.14 \pm 1.74$ and for aqueous extract the polyphenol yield range was from $21.94 \pm 2.06-20.13 \pm 2.78$. Both fresh leaf and made tea of TV 25 variety gave highest polyphenol yields of $31.35 \pm 2.78 \%$ (methanol) and $9.84 \pm 0.79 \%$ (aqueous) respectively. In silico GRIP docking studies showed epi-catechin gallate as the most potent antioxidant. The IC50 values for AChE inhibitory assay of black tea (CTC) was found to be $34.18 \mu \mathrm{g} / \mathrm{mL}$. Amongst three varieties (TV 25, TV 26 and TV 23), both fresh leaf and made tea of TV 25 variety showed maximal poly phenol content with highest antioxidant potential and were found to be comparable to Assam clones in this respect. The same fact is also reflected in the AChE inhibitory assay. Considering the significant polyphenol content and anti-oxidant capacity it can be concluded that these tea polyphenols can serve the purpose of adjuvant therapy in Alzheimer.@ 2015 iGlobal Research and Publishing Foundation. All rights reserved.
\end{abstract}




\section{Indo Global Journal of Pharmaceutical Sciences, 2015; 5(3): 171-191}

\section{INTRODUCTION}

Tea (Camellia sinensis) belonging from family Theaceae is one of the worldwide popular beverages; grown traditionally on the slopes of hills and high plateau of north-east and southern parts of India. It grows well in fertile, well drained, acidic soil with good water retention capacity [1-3]. Consumption of this beverage has increased throughout the world mostly due to its efficacy in combating several chronic to degenerative diseases like Alzheimer [4-6]. Researchers have shown tea as an adjuvant therapy in combating many disease conditions in a non-pharmacologic manner. Health benefits of tea are highly correlated with its total polyphenolic contents (TPC). It has been found that the total phenolic content of Assam clone is more than the Darjeeling clone [1-3]. With changes in soil character, agronomical challenges and climatic adaptability the paper focuses the maintaining yield of Assamese polyphenolic content (Tocklai Vegetative or TV 25, TV 26 and TV 23) in the non-traditional tea growing region of IIT Kharagpur [7-9]. Further the research presents the implementation of Central composite design or CCD of Response Surface Methodology (RSM) or chemometrics for optimizations of the extraction process parameters so as to obtain maximal polyphenol yield; quantitative estimation of polyphenolic contents, in vitro-in silico evaluations of the anti-oxidant properties, and in vitro AChE inhibitory assay of fresh tea leaves and processed clones (TV 23, TV 25 and TV 26) grown in the nontraditional tea garden of IIT Kharagpur $[\mathbf{1 0 , 1 1 ]}$. An in silico approach aided in understanding the antioxidant potential of tea catechin molecules at mechanistic level. Increasing cost of drug development, less availability of new chemical entities (NCE) is one of the bottlenecks in drug development. With the emergence of proteomics, genomics, bioinformatics, NMR and crystallography, more target protein molecules became available. For the identification and analysis of the active sites and potential drug molecules binding to such sites, computational tools like in silico modeling just fits to the purpose [11-17].

Alzheimer disease (AD) is an age related neurodegenerative disorder largely affecting the aged populations worldwide. Aetiopathogenesis of $\mathrm{AD}$ is multi-factorial including aggregation of $\beta$-amyloid and tau protein, oxidative stress due to elevated reactive oxygen species (ROS) levels and reduced acetylcholine (ACh) levels [4-6]. Hence consumptions of antioxidants can be a successful preventive strategy. Although there are no proven modalities for preventing this disease, several attempts have been made to control the worsening conditions in both pharmacologic and non-pharmacologic manner. Due to growing concerns of toxicities and side effects associated with western classical medicines there has been a great resurgence of interest in phytotherapy, nutraceuticals or adjuvant therapy $[\mathbf{5 - 8 , 1 8}$. Tea being the commonest health drink in Eastern Globe, the study may help to establish its nutraceutical potentiality as an adjuvant therapy in early onset of Alzheimer or dementia particularly in Indian context.

\section{MATERIALS \& METHODS}

\section{Chemicals and Reagents}

All chemicals and reagents used for the experimentation were all of analytical grade and were purchased either from Merck (India) and Sigma Aldrich.

\section{Instruments}

Electric grinder (Bajaj GX 11); Centrifuge (Remi, R-8C Lab Centrifuge); UV spectrophotometer (Thermo Scientific); HPLC (Model Waters 2998); GC-MS (Shimadzu QP2010).

\section{Software}

Experimental design, data analysis and surface plots were performed by using Design Expert Trial version 7.0. For GRIP docking studies VLife MDS was used.

\section{Proximate Analysis}

Leaf powders of each tea clones (TV23, TV25, and TV26) were exhaustively processed for various parameters of proximate analysis (carbohydrates, fats, crude protein, moisture, dry matter, crude fiber, nitrogen free extract and ash) according to the Association of Official Analytical Chemists methods (AOAC, 1990) and other standard literature [3].

\section{Optimization of extraction conditions by Response surface Methodology}

An experimental design methodology should be such that it's economical for extracting the maximum amount of complex information with a significant reduction in experimentation time thus saving material and personal cost. Response surface methodology (RSM) using desirability function is a good statistical analysis tool to 


\section{Indo Global Journal of Pharmaceutical Sciences, 2015; 5(3): 171-191}

justify the above statement. RSM finds applications for proper optimization of any process technology and determining the values of process parameters at which response reaches its optimum level. Optimum level can be a maximum, minimum or a desired region where the response is stable over a range of parameters. RSM is useful in quantifying the relationship between one or more measured responses and the important input factor. It consist of three steps i.e. selection of type of response surface method design \& laying of experiment design based on dependent and independent parameters, analysis $\&$ diagnosis and numerical optimization using desirability function. The most popular RSM design is the central composite design (CCD) which has three groups of design points viz. two level factorial or fractional factorial design points, axial points or star points and centre points. The two level factorial part of the design consists of all possible combination of the +1 and -1 level of the factors. The values of the star points are set at zero; the midpoint except one factor has a value of \pm alpha. The centre point as implied by the name are points with all levels set to coded level zero-the midpoint of each factor range $(0,0)$. In this study there are two responses i.e. volume of methanol and weight of sample, selected to maximize the yield of polyphenol at optimum range of respective responses [10].

\section{Preparation of aqueous tea infusions}

Aqueous extracts of fresh tea leaves were prepared as per literature and optimized chemometrically. Fresh tea leaves were collected, washed, pasted with water using electric grinder (Bajaj GX 11) and subjected to aqueous extractions. Briefly, $3.75 \pm 0.04 \mathrm{~g}$ of fresh tea leaves were soxhelated (10 cycles) at $30{ }^{\circ} \mathrm{C}$, filtered, concentrated (Rota evaporation) and dried in hot air oven $\left(50^{\circ} \mathrm{C}\right)$. Later extracts were scrapped and stored at $-20{ }^{\circ} \mathrm{C}$ for future estimations.

In case of made tea (black tea, CTC variety), $2 \mathrm{~g}$ of tea was added to $100 \mathrm{~mL}$ of boiled water and steeped for 15 min [ISO TC 34/SC 8; http://www.rsc.org]. Extracts were filtered by Whatmann No.1 filter paper for removal of residues. Filtrates were centrifuged (Remi, R-8C Lab Centrifuge) at $5000 \mathrm{rpm}$ for $20 \mathrm{~min}$ and the supernatants were collected, concentrated (rota evaporation) and dried in hot air oven $\left(50{ }^{\circ} \mathrm{C}\right)$. Later extracts were scrapped and stored at $-20{ }^{\circ} \mathrm{C}$ for future estimations $[2,10]$.

\section{Preparation of Methanol extract}

Methanolic extracts of fresh tea leaves were prepared as per literature and optimized chemometrically. $3.75 \pm 0.04$ $\mathrm{g}$ of fresh tea leaves were soxhelated with $207.32 \pm 0.01$ $\mathrm{mL}$ of $80 \% \mathrm{v} / \mathrm{v}$ methanol for 10 cycles at $35{ }^{\circ} \mathrm{C}$; later methanol was evaporated by rotary evaporator (Han vapor) and the remaining residue was lyophilized to get the dehydrated powdered form and stored at $-20{ }^{\circ} \mathrm{C}$ for further estimations.

Methanolic extract of made tea (CTC variety) was prepared maintaining the same sample weight (2 $\mathrm{g}$ of made tea) and solvent volume (100 $\mathrm{ml}$ methanol) as per ISO method followed in case of aqueous extract of made tea so as to maintain homogeneity amongst the two extraction procedures of made tea. After 10 soxhelations at $35{ }^{\circ} \mathrm{C}$, extracts were filtered by Whatmann No.1 filter paper for removal of residues. Filtrates were centrifuged (Remi, R-8C lab centrifuge) at $5000 \mathrm{rpm}$ for $20 \mathrm{~min}$ and the supernatants were collected, concentrated (rota evaporation) and dried in hot air oven $\left(50{ }^{\circ} \mathrm{C}\right)$. Later extracts were scrapped and stored at $-20{ }^{\circ} \mathrm{C}$ for future estimations.

The percent yield of the extract in all cases was determined by the following formula:

Percent yield $(\%)=\frac{\text { Weight of extract }}{\text { Weight of leaf powder taken }} \times 100$

\section{Estimations of polyphenols and flavonoids by UV spectroscopy}

\section{Polyphenol estimation}

Total polyphenol content (TPC) of the extracts was determined as per the literatures methods of Othman et al., 2007 [19] and Modnicki et al., 2009 [20] using FolinCiocalteu (FC) reagent. The absorbances of the samples were determined at $760 \mathrm{~nm}$ by UV spectrophotometer (Perkin Elmer Lambda $25 \mathrm{UV}$-vis). The poly phenol content was calculated from the standard calibration curve and calculated in terms of gallic acid equivalents (GAE) per gram of the extract [19-23].

\section{Flavonoid estimation}

Total flavonoid content (TFC) of the extracts was determined as per literature method which is based on the formation of a complex of flavonoid-aluminium and the absorbance measured at $430 \mathrm{~nm}$. The concentration of the flavonoids was 


\section{Indo Global Journal of Pharmaceutical Sciences, 2015; 5(3): 171-191}

deduced from the standard curve and calculated in terms of quercetin equivalent (QE) per gram of the extract [19-23].

\section{HPLC method for estimations of polyphenols}

Analysis of the components of fresh tea leaf extracts as well as black tea (CTC) was done as per the methodology given by Mandal et al., 2013 [24,25]. Briefly, in case of fresh leaf, about $20 \mathrm{~g}$ of leaves were dipped in liquid nitrogen, crushed and grinded well in mixer. Next $1 \mathrm{~g}$ leaf powder and $20 \mathrm{~mL}$ methanol were mixed well in mortar for $15 \mathrm{~min}$ and filtered through Whatmann filter paper. The final volume was adjusted to $25 \mathrm{~mL}$ with methanol.

HPLC separation (Model Waters 2998) was carried out with RP-C18 column $5 \mu \mathrm{m}(250 \mathrm{~mm} \times 4.6 \mathrm{~mm}$ i.d. $)$ under the following chromatographic conditions: Gradient mobile phase with $0.2 \%$ acetic acid in water (A) and acetonitrile (B); composition of mobile phase was initially set at $8 \%$ of acetonitrile (B) and $92 \%$ of $0.2 \%$ acetic acid in water (solvent A). Solvent B was then gradually increased to $31 \%$ at $25 \mathrm{~min}$, to $40 \%$ at $35 \mathrm{~min}$, to $100 \%$ at $37 \mathrm{~min}$ and hold for $3 \mathrm{~min}$. The PDA detector was set at 200-600 $\mathrm{nm}$ and chromatograms were recorded at 274 $\mathrm{nm}$. Separations were achieved at room temperature with a flow rate of $1 \mathrm{~mL} / \mathrm{min}$ with an injection volume of 20 $\mu 1$. Authenticated standards were used for identifying peaks and calculate the concentration of components in tea samples. Each peak was confirmed by comparing the retention times and absorption spectra of unknowns to that of standard compounds $[\mathbf{2 4 , 2 5}]$.

\section{GC-MS analysis of volatile components of tea samples}

GC-MS analysis was carried out according to the method given by Mandal et al., 2013. Volatile flavor compounds were extracted from tea samples by dynamic headspace sampling techniques. For each extraction, $20 \mathrm{~g}$ of tea leaves were taken in $250 \mathrm{~mL}$ of round bottom flask (RBF) attached with two open arm of $8 \mathrm{~mm}$ diameter. One arm was connected with a charcoal filter through which environmental air enters into the flask. Another arm was connected with an $8 \mathrm{~mm}$ diameter column containing an adsorption bed. The system allows external air to run over the tea samples through the adsorption bed connected to a vacuum pump at a particular flow rate. The air containing the volatile compounds was trapped by the adsorption bed. After $2 \mathrm{~h}$ of extraction at $50^{\circ} \mathrm{C}$ trapped volatiles were eluted from the adsorbing matrix into glass vial with 200 $\mu \mathrm{L}$ of HPLC grade dichloromethane containing $1 \mu \mathrm{L}$ of ethyl hexanoate as an internal standard [25].
The GC-MS analysis was done on Shimadzu QP2010 GC-MS system with column specifications ZB-5 column $(30 \mathrm{~m} \times 0.25 \mathrm{~mm}$ i.d., film thickness $0.25 \mu \mathrm{m})$ under the following chromatographic conditions. Helium was used as the carrier gas, injection volume was $2 \mu \mathrm{L}$ with a split ratio of $2: 1$. The injector temperature was set at $260^{\circ} \mathrm{C}$ and a temperature gradient was maintained with the column oven. Initially column oven temperature of GC was set at $50^{\circ} \mathrm{C}$ for $2 \mathrm{~min}$, then increased to $60^{\circ} \mathrm{C}$ at a rate of $2^{\circ} \mathrm{C}$ per minute, kept constant for $2 \mathrm{~min}$ and further raised to $210^{\circ} \mathrm{C}$ at a rate of $3^{\circ} \mathrm{C}$ per minute, kept constant for $2 \mathrm{~min}$ and finally to $270^{\circ} \mathrm{C}$ at a rate of $10^{\circ} \mathrm{C}$ per minute, and kept constant for $7 \mathrm{~min}$. The column flow rate was maintained at $1 \mathrm{~mL} / \mathrm{min}[25]$.

The MS operating conditions include: ion source temperature maintained at $200^{\circ} \mathrm{C}$, interface temperature at $280^{\circ} \mathrm{C}$, electronic energy at $70 \mathrm{eV}$ and a scanning range of $\mathrm{m} / \mathrm{z}$ 40-600 amu. Data were processed using GC-MS solution version 2.6 software. The compounds were identified by comparing MS of the component to that of mass spectral library from NIST 05 (National Institute of Standards and Technology, Gaithersburg, USA) and Wiley 8.0 (Wiley, New York, USA). The area $(\mu \mathrm{V})$ was calculated from TIC (total ion chromatogram) automated computerized integrator [25].

\section{In vitro Antioxidant Assays}

\section{DPPH Free Radical Scavenging Activity}

The antioxidant activity of tea samples was determined on the basis of the scavenging effect on the stable DPPH free radical activity as per literature methods (Fig. 1) [26]. Briefly, $0.2 \mathrm{mM}$ DPPH solution was prepared by dissolving $0.08 \mathrm{~g}$ of DPPH in methanol in a $100 \mathrm{~mL}$ standard flask and volume made up to mark with methanol. Next $1.5 \mathrm{~mL}$ of $0.2 \mathrm{mM}$ DPPH solution and 1.5 $\mathrm{mL}$ of sample solutions in different concentrations were mixed. In another series $1.5 \mathrm{~mL}$ of different concentrations of sample solutions were mixed with 1.5 $\mathrm{mL}$ of methanol. All solutions were kept for $30 \mathrm{~min}$ at room temperature and allowed to react. Absorbance was read at $517 \mathrm{~nm} \mathrm{[26].} \mathrm{Calculations} \mathrm{were} \mathrm{done} \mathrm{basing} \mathrm{on} \mathrm{the}$ equation:

$$
\% \text { of scavenging activity }=\frac{(\mathrm{Ab}+\mathrm{As})-\mathrm{Am}}{\mathrm{Ab}}
$$

where, $\mathrm{Ab}=$ absorbance of $1.5 \mathrm{~mL} \mathrm{DPPH}+1.5 \mathrm{~mL}$ methanol; $\mathrm{Am}=$ absorbance of $1.5 \mathrm{~mL} \mathrm{DPPH}+1.5 \mathrm{~mL}$ 


\section{Indo Global Journal of Pharmaceutical Sciences, 2015; 5(3): 171-191}

sample solution; As= absorbance of $1.5 \mathrm{~mL}$ sample solution $+1.5 \mathrm{~mL}$ methanol. Plotting was done of percent inhibition versus concentration, and the concentration of sample required for $50 \%$ inhibition is regarded as $\mathrm{IC}_{50}$ value for each of the test samples.

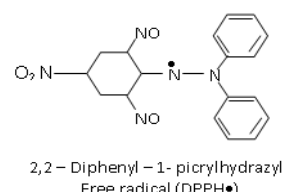

Free radical (DPPH•) (coloured)
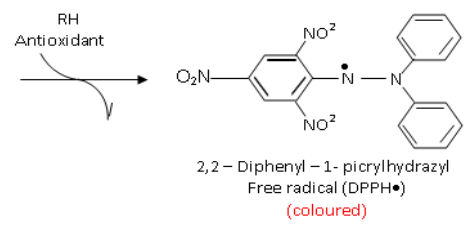

Figure1. Reaction between antioxidant and DPPH radical

\section{Total Antioxidant Activity (FRAP assay)}

Total antioxidant activity was determined by the FRAP assay as per the standard operating procedure laid down by literature with slight modifications $[\mathbf{2}, \mathbf{2 6 - 3 0}]$. The procedure is based on the reduction of ferric to ferrous form in the presence of antioxidants in the tea samples (Fig.2). The stock solutions included $10 \mathrm{mM}$ 2,4,6tripyridyl-s-triazine (TPTZ) in $40 \mathrm{mM} \mathrm{HCl}$ and $20 \mathrm{mM}$ $\mathrm{FeCl}_{3}$; and $300 \mathrm{mM}$ acetate buffer (pH 3.6). A $30 \mathrm{mM}$ acetate buffer was prepared by dissolving $3.1 \mathrm{~g}$ of sodium acetate in $16 \mathrm{~mL}$ glacial acetic acid and volume adjusted with distilled water to $1 \mathrm{~L} ; 40 \mathrm{mM} \mathrm{HCl}$ was prepared by diluting $1.46 \mathrm{~mL}$ concentrated $\mathrm{HCl}(11 \mathrm{M})$ with distilled water upto $1 \mathrm{~L} ; 10 \mathrm{mM}$ TPTZ solution was prepared by dissolving $0.031 \mathrm{~g}$ TPTZ in $10 \mathrm{~mL}$ of $40 \mathrm{mM} \mathrm{HCl}$. The working solutions were freshly prepared by mixing $25 \mathrm{~mL}$ acetate buffer, $2.5 \mathrm{~mL}$ TPTZ and $2.5 \mathrm{~mL}$ of $\mathrm{FeCl}_{3}$. The temperature of the solution was raised to $37{ }^{\circ} \mathrm{C}$ prior to use. Tea samples $(200 \mu \mathrm{L})$ were allowed to react with FRAP solution (2900-3000 $\mu \mathrm{L}$ ) for $30 \mathrm{~min}$ in the dark. Absorbance of the colored product formed (ferrous tripyridyl triazine complex) was recorded at $595 \mathrm{~nm}$. Results were expressed in $\mu \mathrm{M}$ equivalent to $\mathrm{FeSO}_{4}$ by extrapolation from the calibration curve.

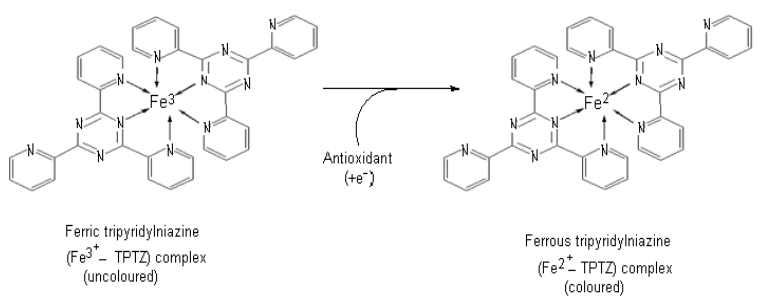

Figure 2. Reduction reaction of Fe (III)-TPTZ complex

\section{ABTS (2, 2'-azinobis (3-ethylbenzothiazoline-6-sulfonic acid) assay}

The assay was carried out according to literature with slight modifications [2, 26, 28-30]. The main principle is based on the ability of test samples to scavenge 2,2'azino-bis (ethylbenzthiazoline-6-sulphonic acid or $\mathrm{ABTS}^{+}$) radical cation (Fig.3). The radical cation was prepared by mixing $7 \mathrm{mM}$ ABTS stock solution with 2.45 $\mathrm{mM}$ potassium per-sulfate $(1 / 1, \mathrm{v} / \mathrm{v})$, leaving the mixture for 4-16 $\mathrm{h}$ for completion of reaction and getting a stable absorbance. The $\mathrm{ABTS}^{+}$solution was diluted with ethanol to get an absorbance of $0.700 \pm 0.05$ at $734 \mathrm{~nm}$ for measurements. The photometric assay was conducted on $0.9 \mathrm{~mL}$ of $\mathrm{ABTS}^{+}$solution and $0.1 \mathrm{~mL}$ of tested samples (100 and $200 \mu \mathrm{g} / \mathrm{mL}$ ), mixed for $45 \mathrm{sec}$ and measurements taken immediately at $734 \mathrm{~nm}$ after $15 \mathrm{~min}$. The anti-oxidative activities of the tested samples were calculated by determining the decrease in absorbance at different concentrations by using the equation:

$E=\left[\left(A_{c}-A_{t}\right) / A_{c}\right] X 100$ where $A_{t}$ and $A_{c}$ are the respective absorbance of tested samples and $\mathrm{ABTS}^{+}$ expressed as $\mu \mathrm{M}$.

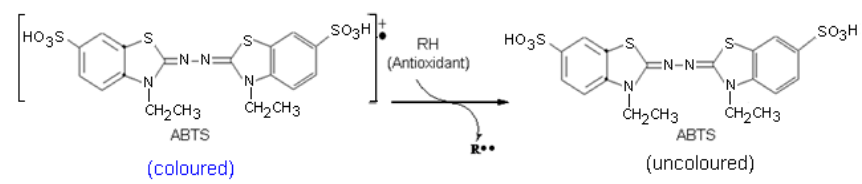

Figure 3. Reaction between ABTS radical and antioxidant

\section{Rapid screening of antioxidant activity by Dot-Blot assay}

Rapid screening of antioxidant property by dot blot assay with DPPH staining was carried out as per the literature [31]. An aliquot of each dilution of different tea leaf extracts, eugenol and epigallocatechin gallate was loaded on a $10 \times 20 \mathrm{~cm}$ silica gel (60) TLC plate (Merck) and allowed to dry. Drops of each sample were loaded in order of decreasing concentrations along the column. The staining of silica plate was done by dipping the plate in $0.4 \mathrm{mM}$ DPPH solution in methanol for 2-3 sec. The intensity of the yellow color depends upon the amount and nature of radical scavenger present in the sample. 


\section{Indo Global Journal of Pharmaceutical Sciences, 2015; 5(3): 171-191}

\section{In silico docking studies}

\section{Proteins used for GRIP Docking}

Copper-zinc superoxide dismutase (4B3E), glutathione peroxidase (3KIJ) and erythrocyte catalase (1DGB) of Homo sapiens were used for the current study. Their PDB structures were taken from RCSB.

\section{Docking studies}

Vlife MDS 4.4 is very robust software with inclusion of all the necessary simulation modules. The 2D-structures of catechin (C), epicatechin (EC), epicatechin gallate (ECG), epigallo catechin (EGC) and epigallocatechin gallate (EGCG) under study were drawn in the 2D drawing application (2D Draw app) of MDS 4.4, followed by its conversion into $3 \mathrm{D}$ form by using default conversion procedure (Fig. 12-14). By using Merck Molecular Force Field (MMFF) as force field, their energy minimization was done. MMFF is a class II force field designed to be a transferable force field for pharmaceutical compounds that accurately treats conformational energetics and non-bonded interactions. Molecular docking energy evaluations are usually carried out with the help of scoring function like dock score, PLP score, potential mean force (PMF) score, steric and electrostatic score. PLP score or Piecewise Linear Potential scoring function calculates both the shape and hydrogen bond complementarity of poses to the active site. The PLP score is a pair wise additive scoring function. The PLP function is incorporated by the MDS VLife Science software in the GRIP docking method which calculates the ligand-receptor binding affinity in terms of the PLP score. The PLP score is designed to enable flexible docking of ligands to perform a full conformational and positional search within a rigid binding site. These molecules were docked into the active site of 4B3E (copper-zinc superoxide dismutase), 3KIJ (crystal structure of human peroxidase) and 1DGB (catalase) that can be obtained as co-crystallized with bicarbonate ion or NADPH or by the use of cavities. The parameters fixed for docking simulation were: number of placements is 100 , rotation angle at $10^{\circ}$, exhaustive method, ligand-wise results-10, scoring function-PLP score. By rotation angle, ligand would be rotated inside the receptor cavity to generate different poses of ligand inside the receptor cavity. By placements, the method will check all the 100 possible placements into the active site pocket and will result the best placements out of 100 . After docking simulation, the best docked conformer of test molecules and reference ligands were then checked for their interactions with targeted proteins like hydrogen bonding, hydrophobic, pi-staking/aromatic, charge and van der Waal's interactions [12-17, 32].

\section{In vitro $\mathrm{AChE}$ inhibitory assay}

Inhibition of AChE, the key enzyme in the breakdown of acetylcholine, is considered as one of the treatment strategies against several neurological disorders including Alzheimer [33]. The test relies on the cleavage by AChE of 1-naphthyl acetate to form $\alpha$-naphthol, which in turn reacts with fast blue $B$ salt to give a purple colored diazonium dye. AChE activity was measured using 1naphthyl acetate as a substrate. Production of 1-naphthol was monitored spectrophotometrically using both a sample and a reference quartz cuvette $(1 \mathrm{ml})$ with path length of $1 \mathrm{~cm}$. Firstly, continuous spectrophotometric assay of normal enzyme catalyzed reaction was carried out and product formation was monitored. Absorbance was measured at $320 \mathrm{~nm}$ for $5 \mathrm{~min}$ at $0.5 \mathrm{~min}$ intervals as absorption maxima of the product $\alpha$-naphthol is $320 \mathrm{~nm}$. The control reaction mixture $(1 \mathrm{ml})$ contained $710 \mu \mathrm{l}$ of $50 \mathrm{mM}$ potassium phosphate buffer ( $\mathrm{pH} \mathrm{7}$ ), $250 \mu \mathrm{l}$ of 2 $\mathrm{mM}$ substrate and $40 \mu \mathrm{l}$ of enzyme solution. Then $50 \mu \mathrm{l}$ $(1 \mathrm{mg} / \mathrm{ml})$ of tea extract solution was introduced along with $660 \mu \mathrm{l}$ of buffer, $250 \mu \mathrm{l}$ of $2 \mathrm{mM}$ substrate and $40 \mu \mathrm{l}$ of enzyme solution. Again the product formation was monitored keeping all the conditions same. The enzyme activity was calculated by using following formula:

$$
\begin{gathered}
1 \mathrm{U}=(\Delta \mathrm{A} X 1) /(\mathrm{C} \mathrm{X} \mathrm{0.04)} \\
\Delta \mathrm{A}=(\mathrm{A} 2-\mathrm{A} 1) / \mathrm{T}
\end{gathered}
$$

where, $\mathrm{A} 2=$ Final absorbance value at time $=5 \mathrm{~min} ; \mathrm{A} 1$ $=$ Initial absorbance value at time $=0 \mathrm{~min} ; \Delta \mathrm{A}=$ Change in absorbance; $\mathrm{T}=$ Total time $(5 \mathrm{~min}) ; \mathrm{C}=$ Molar extinction coefficient of 1 naphthol $=2,222 \mathrm{M}-1 \mathrm{~cm}-1 ; 1$ $=$ Volume of total reaction mixture $(1 \mathrm{ml})=$ dilution factor; $0.04=$ Volume of enzyme solution in the reaction mixture $(0.04 \mathrm{ml})$.

\section{RESULTS \& DISCUSSION}

The result of proximate analysis of fresh tea leaves and made tea are provided in Table 1. Actual and coded design layout for central composite design (CCD) of the experiment has been provided in Table $\mathbf{2}$ and the corresponding 3D surface plots of polyphenol yields in Fig. 4. The yield of aqueous and methanolic extracts of fresh tea leaves and made tea are given in Table 3. The 


\section{Indo Global Journal of Pharmaceutical Sciences, 2015; 5(3): 171-191}

results of UV analysis of total polyphenol content (TPC), catechin and total flavonoid content (TFC) of the aqueous and methanolic extracts of fresh tea leaves and made tea of three varieties are represented in Table 4. For detection of the polyphenolic contents, the samples were scanned in the range of $200-760 \mathrm{~nm}$ and the peaks present within this scanned range indicates the presence of phenolic compounds [Fig. 5 (A-C)]. Similarly, catechins were detected in the scan range of 200-600 $\mathrm{nm}$ and the maximum detection was obtained at $274 \mathrm{~nm}$. The standard calibration curves for gallic acid and quercetin are presented in Fig.6. The results of HPLC analysis of both fresh leaves and made tea are provided in Table 5-6 and Fig.7-8. Results of GC-MS analysis are presented in Table 7 and Fig.9. In vitro antioxidant assays like DPPH radical scavenging assay of fresh leaf and made tea are presented in Table 8, and FRAP and ABTS assay in Fig.10. The results of dot blot assays are shown in Fig. 11 and that of in silico docking studies are provided in Table 9-11 and Fig.12 (a-e); Fig.13 (a-d); Fig.14 (a-h). The percent inhibition of $\mathrm{AChE}$ by different black tea extracts is presented in Table $\mathbf{1 2}$.

The values of proximate analysis of fresh tea leaves and made tea (TV 25, TV 23 and TV 26) grown at IIT Kharagpur were found to be compatible with the values obtained from Assam clones.
Considering the 3D surface plots of three varieties of tea, the normal plot of residuals of three tea varieties (both aqueous and methanolic extract) shows very less scattering and fits almost to a straight line. Prediction for desirability of TV 23 fresh leaf methanol extract and aqueous extracts were 0.749 and 0.788 respectively. Prediction for desirability of TV 25 methanolic and aqueous extracts were 0.709 and 0.729 respectively. For TV 26 fresh leaf methanolic and aqueous extracts, the prediction for desirability were found to be 0.677 and 0.743 respectively. From the solution obtained using desirability function it was found that for all the varieties (TV 25, TV 26 and TV 23) volume of methanol was within the range of 207.32-208.12 mL, sample weight in the range of 3.43-3.81 $\mathrm{g}$ and prediction value for polyphenols yield in the range of $25.18 \%$ to $31.3 \%$. However on practical experimentation it was found that TV 25 variety with a sample weight of $3.75 \pm 0.04 \mathrm{~g}$ and methanol volume of $207.32 \pm 0.01 \mathrm{~mL}$ gave maximum polyphenol yield followed by TV 26 and TV23 (Fig. 4).

The color of the aqueous and methanolic extracts of the three varieties obtained were light and dark brown respectively. The percent yield of the aqueous extracts ranged from $21.03 \%$ to $22.7 \%$ and that of methanolic extracts ranged from $23.12 \%$ to $24.45 \%$. Yield was found to be slightly higher amongst methanolic extracts than the aqueous ones.

Table 1 Proximate analysis of different fresh tea leaves made tea (CTC) of TV varieties.

\begin{tabular}{|c|c|c|c|c|c|c|c|c|}
\hline \multirow{2}{*}{$\begin{array}{l}\text { Character } \\
\text { Parameters }\end{array}$} & \multicolumn{2}{|c|}{ TV 25} & \multicolumn{2}{|c|}{ TV 26} & \multicolumn{2}{|c|}{ TV 23} & \multicolumn{2}{|c|}{ Assam clones } \\
\hline & $\begin{array}{l}\text { Fresh } \\
\text { Leaves }\end{array}$ & Made Tea & $\begin{array}{l}\text { Fresh } \\
\text { Leaves }\end{array}$ & Made Tea & $\begin{array}{l}\text { Fresh } \\
\text { Leaves }\end{array}$ & Made Tea & $\begin{array}{l}\text { Fresh } \\
\text { Leaves }\end{array}$ & $\begin{array}{l}\text { Made } \\
\text { Tea }\end{array}$ \\
\hline Ash value & $5.14 \pm 0.1$ & $5.13 \pm 0.4$ & $5.12 \pm 0.3$ & $5.12 \pm 0.2$ & $5.24 \pm 0.1$ & $5.31 \pm 0.2$ & $5-5.5$ & $5-5.5$ \\
\hline Protein content & $14.78 \pm 0.3$ & $14.9 \pm 0.2$ & $15.21 \pm 0.1$ & $15.2 \pm 0.1$ & $14.94 \pm 0.3$ & $14.7 \pm 0.3$ & $14-17$ & $14-17$ \\
\hline $\begin{array}{l}\text { Carbohydrate } \\
\text { content }\end{array}$ & $21.56 \pm 0.2$ & $10.2 \pm 0.1$ & $21.79 \pm 0.4$ & $10.1 \pm 0.3$ & $22.14 \pm 0.1$ & $10.05 \pm 0.2$ & $20-22$ & $10-12$ \\
\hline
\end{tabular}


Indo Global Journal of Pharmaceutical Sciences, 2015; 5(3): 171-191

Table 2 Actual and coded values for layout of Central composite design for optimizing extraction process of methanolic fresh tea leaves.

\begin{tabular}{|c|c|c|c|c|c|}
\hline $\begin{array}{l}\text { Run number } \\
\text { (TV25 Variety) }\end{array}$ & \multicolumn{2}{|c|}{ Factor 1 A:Wt. of sample (g) } & \multicolumn{2}{|c|}{$\begin{array}{l}\text { Factor } 2 \text { B:Vol. of sample } \\
\text { (Methanol) mL }\end{array}$} & $\begin{array}{l}\text { Yield of poly } \\
\text { phenols }(\%)\end{array}$ \\
\hline 1 & 1.414 & 5.00 & 0.000 & 225.00 & 32.91 \\
\hline 2 & -1.000 & 3.29 & -1.000 & 207.32 & 29.91 \\
\hline 3 & 1.000 & 4.71 & 1.000 & 242.68 & 32.11 \\
\hline 4 & 0.000 & 4.00 & 0.000 & 225.00 & 31.29 \\
\hline 6 & 0.000 & 4.00 & 0.000 & 225.00 & 31.71 \\
\hline 7 & 1.000 & 4.71 & -1.000 & 207.32 & 32.87 \\
\hline 8 & 0.000 & 4.00 & -1.414 & 200.00 & 31.97 \\
\hline 9 & 0.000 & 4.00 & 0.000 & 225.00 & 31.47 \\
\hline 13 & -1.414 & 3.00 & 0.000 & 225.00 & 29.39 \\
\hline \multicolumn{6}{|l|}{ (TV26 Variety) } \\
\hline 1 & -1.000 & 3.29 & 1.000 & 242.68 & 26.78 \\
\hline 2 & 1.000 & 4.71 & -1.000 & 207.32 & 29.79 \\
\hline 3 & 0.000 & 4.00 & 0.000 & 225.00 & 28.58 \\
\hline 4 & 0.000 & 4.00 & 0.000 & 225.00 & 28.48 \\
\hline 5 & 0.000 & 4.00 & 0.000 & 225.00 & 28.55 \\
\hline 6 & 0.000 & 4.00 & 1.414 & 250.00 & 28.05 \\
\hline 13 & 0.000 & 4.00 & 0.000 & 225.00 & 28.76 \\
\hline \multicolumn{6}{|l|}{ (TV23 Variety) } \\
\hline 1 & 0.000 & 4.00 & 0.000 & 225.00 & 25.87 \\
\hline 2 & 0.000 & 4.00 & -1.414 & 200.00 & 26.38 \\
\hline 3 & 1.000 & 4.71 & 1.000 & 242.68 & 26.55 \\
\hline 4 & 1.414 & 5.00 & 0.000 & 225.00 & 26.98 \\
\hline 5 & -1.000 & 3.29 & 1.000 & 242.68 & 22.48 \\
\hline 6 & 0.000 & 4.00 & 0.000 & 225.00 & 25.29 \\
\hline 7 & 1.000 & 4.71 & -1.000 & 207.32 & 26.98 \\
\hline 8 & 0.000 & 4.00 & 0.000 & 225.00 & 25.59 \\
\hline 9 & 0.000 & 4.00 & 0.000 & 225.00 & 25.87 \\
\hline 10 & -1.000 & 3.29 & -1.000 & 207.32 & 22.37 \\
\hline 11 & -1.414 & 3.00 & 0.000 & 225.00 & 21.77 \\
\hline 12 & 0.000 & 4.00 & 1.414 & 250.00 & 25.18 \\
\hline 13 & 0.000 & 4.00 & 0.000 & 225.00 & 25.69 \\
\hline
\end{tabular}


Indo Global Journal of Pharmaceutical Sciences, 2015; 5(3): 171-191

Table 3 Yield of different fresh tea leaves and made tea (CTC) of TV varieties.

\begin{tabular}{lllllll}
\hline Character & \multicolumn{2}{l}{ Type of extract } & \multicolumn{2}{l}{ Color of extract } & Yield (\%w/w) \\
Tea clone varieties & Fresh Leaves & Made Tea & Fresh Leaves & Made Tea & Fresh Leaves & Made Tea \\
\hline TV 25 & Aqueous & Aqueous & Light brown & Brown & 22.5 & 20.5 \\
TV 26 & Aqueous & Aqueous & Light brown & Brown & 22.7 & 21.3 \\
TV 23 & Aqueous & Aqueous & Light brown & Brown & 21.03 & 22.1 \\
TV 25 & Methanolic & Methanolic & Dark brown & Dark brown & 24.45 & 24.9 \\
TV 26 & Methanolic & Methanolic & Dark brown & Dark brown & 23.78 & 20.1 \\
TV 23 & Methanolic & Methanolic & Dark brown & Dark brown & 23.12 & 21.2 \\
\hline
\end{tabular}

Table 4 UV estimations of polyphenol and flavonoid content in different fresh tea leaves and made tea (CTC) of TV varieties.

\begin{tabular}{|c|c|c|c|c|c|c|c|c|}
\hline \multirow{3}{*}{$\begin{array}{l}\text { Variety of } \\
\text { Tea Clone }\end{array}$} & \multicolumn{8}{|c|}{ UV estimations of Polyphenol and Flavonoid of fresh and made tea extracts } \\
\hline & \multicolumn{4}{|c|}{ Total Polyphenol (TPC) } & \multicolumn{4}{|c|}{ Total Flavonoid (TFC) } \\
\hline & Methanol & Water & Methanol & Water & Methanol & Water & Methanol & Water \\
\hline TV26 & $28.27 \pm 1.97$ & $20.16 \pm 2.56$ & $8.96 \pm 1.19$ & $4.51 \pm 1.11$ & $22.51 \pm 2.14$ & $16.28 \pm 1.79$ & $6.26 \pm 1.14$ & $2.41 \pm 1.15$ \\
\hline TV23 & $25.14 \pm 1.74$ & $20.13 \pm 2.78$ & $7.62 \pm 1.21$ & $3.74 \pm 1.31$ & $18.24 \pm 1.69$ & $15.97 \pm 1.32$ & $5.52 \pm 1.13$ & $1.94 \pm 1.56$ \\
\hline
\end{tabular}

Table 5 Major compounds of fresh tea leaves of TV varieties detected by HPLC analysis.

\begin{tabular}{lllllll}
\hline Bio-actives & \multicolumn{3}{c}{ Concentration of Major Compounds of Fresh Tea Leaf extracts } \\
\hline & TV25 & \multicolumn{3}{c}{ TV26 } & & TV23 \\
\cline { 2 - 7 } & Methanol & Water & Methanol & Water & Methanol & Water \\
\hline Gallic Acid & $2.61 \pm 0.51$ & $2.59 \pm 0.17$ & $2.41 \pm 0.17$ & $1.49 \pm 0.17$ & $2.11 \pm 0.18$ & $1.19 \pm 0.13$ \\
GC & ND & ND & $1.51 \pm 0.24$ & ND & ND & ND \\
C & $2.15 \pm 0.13$ & $2.03 \pm 0.21$ & $2.34 \pm 0.46$ & $1.53 \pm 0.29$ & $2.03 \pm 0.25$ & $1.17 \pm 0.31$ \\
EC & $12.18 \pm 0.87$ & $10.46 \pm 1.17$ & $16.93 \pm 1.35$ & $7.46 \pm 1.19$ & $10.46 \pm 1.71$ & $11.46 \pm 1.57$ \\
EGC & $102.14 \pm 2.67$ & $39.39 \pm 2.45$ & $61.78 \pm 2.25$ & $36.39 \pm 2.45$ & $42.39 \pm 2.18$ & $24.39 \pm 2.45$ \\
ECG & $29.60 \pm 1.13$ & $4.47 \pm 0.71$ & $27.52 \pm 1.61$ & $2.47 \pm 0.31$ & $24.47 \pm 0.78$ & $1.47 \pm 0.41$ \\
GCG & $2.47 \pm 0.26$ & $1.02 \pm 0.13$ & ND & ND & $1.02 \pm 0.14$ & $0.62 \pm 0.14$ \\
EGCG & $137.61 \pm 3.14$ & $17.39 \pm 1.45$ & $82.26 \pm 3.57$ & $11.39 \pm 1.55$ & $77.39 \pm 2.15$ & $13.39 \pm 1.75$ \\
CG & ND & ND & ND & ND & ND & ND \\
TF & ND & ND & ND & ND & ND & ND \\
TF3MG & ND & ND & ND & ND & ND & ND \\
TF3 MG & ND & ND & ND & ND & ND & ND \\
TF3,3 ${ }^{2}$ NG & ND & ND & ND & ND & ND & ND \\
\hline
\end{tabular}

*The compounds CG, TF, TF3MG, TF3'MG, and TF3,3DG were not detectable (ND) in all extracts. 
Indo Global Journal of Pharmaceutical Sciences, 2015; 5(3): 171-191

Table 6 Major compounds in aqueous extract of TV varieties of made tea (CTC) by HPLC analysis.

\begin{tabular}{|c|c|c|c|}
\hline Compound & TV25 & TV26 & TV23 \\
\hline Gallic Acid & $2.17 \pm 0.52$ & $1.47 \pm 0.32$ & $2.05 \pm 0.59$ \\
\hline GC & ND & ND & ND \\
\hline $\mathrm{C}$ & ND & ND & ND \\
\hline $\mathrm{EC}$ & $4.21 \pm 0.82$ & $2.41 \pm 0.62$ & ND \\
\hline EGC & ND & ND & ND \\
\hline ECG & $1.5 \pm 0.12$ & $1.15 \pm 0.17$ & $1.12 \pm 0.22$ \\
\hline GCG & $1.52 \pm 0.32$ & $1.12 \pm 0.22$ & $1.72 \pm 0.36$ \\
\hline EGCG & $2.1 \pm 1.02$ & $2.1 \pm 1.52$ & $1.71 \pm 1.72$ \\
\hline $\mathrm{CG}$ & $3.43 \pm 0.87$ & $1.43 \pm 0.67$ & ND \\
\hline $\mathrm{TF}$ & $1.31 \pm 0.12$ & $1.11 \pm 0.17$ & $0.29 \pm 0.11$ \\
\hline TF3MG & $2.72 \pm 0.45$ & $0.56 \pm 0.47$ & $1.72 \pm 0.45$ \\
\hline TF3 ${ }^{\prime} \mathrm{MG}$ & $1.54 \pm 0.23$ & $1.14 \pm 0.13$ & $0.19 \pm 0.13$ \\
\hline TF3,3'DG & $2.45 \pm 0.71$ & $1.45 \pm 0.31$ & $0.49 \pm 0.21$ \\
\hline
\end{tabular}

Note: Concentration is represented at $\mathrm{mg} \mathrm{g}^{-1} 1$ dry weight tea. All data are expressed as mean $\pm \mathrm{SD}$. Results are representative of three independent experiments. $\mathrm{GC}=$ Gallo catechin; $\mathrm{C}=$ Catechin; $\mathrm{EC}=(-)$ Epicatechin; $\mathrm{EGC}=(-)$ Epigallocatechin; ECG= $(-)$ Epicatechin gallate; $\mathrm{GCG}=(-)$ Gallocatechin gallate; $\mathrm{EGCG}=(-)$ Epigallocatechin gallate; $\mathrm{CG}=$ Catechin gallate; $\mathrm{TF}=\mathrm{Theaflavin} ; \mathrm{TF} 3 \mathrm{MG}=$ Theaflavin-3-mono gallate; TF3 'MG= Theaflavin-3'-mono gallate; TF3, $3^{\prime}$ DG= Theaflavin-3, 3'-di gallate; ND= Not detectable.

Table 7 Data of GC-MS analysis of volatile flavor compounds in made tea (CTC) of TV25 variety.

\begin{tabular}{|c|c|c|c|}
\hline $\begin{array}{l}\text { Peak } \\
\text { No. }\end{array}$ & Compound Name & Retention Time & Relative Area \\
\hline 1. & 2-Hexenal & 6.022 & 0.002 \\
\hline 2. & Heptanal & 7.894 & 0.007 \\
\hline 3. & Octanal & 13.69 & 0.010 \\
\hline 4. & Phenyl acetaldehyde & 15.839 & 0.065 \\
\hline 5. & Linalool oxide ( cis, furanoid) & 17.49 & 0.025 \\
\hline 6. & Linalool oxide ( trans, furanoid) & 18.395 & 0.031 \\
\hline 7. & Undecane & 19.129 & 0.013 \\
\hline 8. & Linalool & 19.358 & 0.201 \\
\hline 9. & 1,5,7-Octatrien-3-ol,3,7-dimethyl & 19.505 & 0.034 \\
\hline 10. & 2- Phenylethanol & 20.247 & 0.068 \\
\hline 11. & 2,5-Pyrrolidinedione, 1-ethyl & 21.085 & 0.019 \\
\hline 12. & 2-Nonenal & 22.373 & 0.028 \\
\hline 13. & Linalool oxide (cis, pyranoid) & 23.364 & 0.046 \\
\hline 14. & Methyl salicylate & 24.281 & 0.101 \\
\hline 15. & Dodecane & 24.591 & 0.098 \\
\hline 16. & Decanal & 24.814 & 0.030 \\
\hline 17. & $\beta$-Cyclocitral & 25.48 & 0.031 \\
\hline 18. & Geraniol & 27.36 & 0.017 \\
\hline 19. & Tridecane & 29.646 & 0.138 \\
\hline 20. & Cis-3-Hexenyl Hexanoate & 33.309 & 0.019 \\
\hline 21. & Tetradecane & 34.349 & 0.147 \\
\hline 22. & $\alpha$-Ionone & 35.436 & 0.027 \\
\hline 23. & Cis-Geranylacetone & 36.52 & 0.023 \\
\hline 24. & $\beta$-Lonone & 38.033 & 0.064 \\
\hline 25. & Pentadacane & 38.685 & 0.019 \\
\hline 26. & $\alpha$-Farnesene & 39.051 & 0.087 \\
\hline 27. & Benzofuranone & 39.98 & 0.043 \\
\hline 28. & Nerolidol & 41.41 & 0.027 \\
\hline 29. & Hexadacane & 42.86 & 0.053 \\
\hline
\end{tabular}


Indo Global Journal of Pharmaceutical Sciences, 2015; 5(3): 171-191

Table 8 DPPH radical scavenging activity of different aqueous tea extracts of TV varieties.

\begin{tabular}{|c|c|c|c|c|c|c|c|c|}
\hline \multirow[t]{2}{*}{ Variety } & \multicolumn{2}{|l|}{$50 \mu \mathrm{g} / \mathrm{mL}$} & \multicolumn{2}{|l|}{$100 \mu \mathrm{g} / \mathrm{mL}$} & \multicolumn{2}{|l|}{$200 \mu \mathrm{g} / \mathrm{mL}$} & \multicolumn{2}{|l|}{$300 \mu \mathrm{g} / \mathrm{mL}$} \\
\hline & $\begin{array}{l}\text { Fresh } \\
\text { Leaves }\end{array}$ & Made Tea & $\begin{array}{l}\text { Fresh } \\
\text { Leaves }\end{array}$ & Made Tea & $\begin{array}{l}\text { Fresh } \\
\text { Leaves }\end{array}$ & Made Tea & $\begin{array}{l}\text { Fresh } \\
\text { Leaves }\end{array}$ & Made Tea \\
\hline TV25 & $25.43 \pm 1.78$ & $15.43 \pm 1.28$ & $42.78 \pm 2.06$ & $31.78 \pm 1.16$ & $74.75 \pm 2.14$ & $65.75 \pm 1.14$ & $75.76 \pm 1.16$ & $65.16 \pm 1.06$ \\
\hline $\begin{array}{l}\text { TV26 } \\
\text { TV23 }\end{array}$ & $\begin{array}{l}28.27 \pm 1.97 \\
25.14 \pm 1.74\end{array}$ & $\begin{array}{l}16.27 \pm 1.25 \\
16.14 \pm 1.14\end{array}$ & $\begin{array}{l}41.16 \pm 2.56 \\
45.21 \pm 2.78\end{array}$ & $\begin{array}{l}32.26 \pm 1.26 \\
34.87 \pm 2.92\end{array}$ & $\begin{array}{l}77.5 \pm 1.13 \\
72.0 \pm 1.11\end{array}$ & $\begin{array}{l}64.5 \pm 2.19 \\
63.0 \pm 1.23\end{array}$ & $\begin{array}{l}78 \pm 2.75 \\
73 \pm 1.41\end{array}$ & $\begin{array}{l}67.23 \pm 1.55 \\
66.21 \pm 1.11\end{array}$ \\
\hline
\end{tabular}

Table 9 Docking studies of tea polyphenols with protein $4 \mathrm{b3e}$ (copper-zinc superoxide dismutase of Homo sapiens).

\begin{tabular}{|c|c|c|c|}
\hline Compound & Best Pose & Binding Interactions of Best Pose & $\begin{array}{l}\text { Scoring } \\
\text { Function }\end{array}$ \\
\hline ++Epicatechin & Epicatechin_opt_C2_LP9 & $\begin{array}{l}\text { VDW: His48A, Thr58A, His120A, Thr137A, Ala140A, } \\
\text { Gly141A, Arg143A } \\
\text { HYI: Thr58A, Arg143A } \\
\text { CI: N/A } \\
\text { HB: N/A }\end{array}$ & -48.08 \\
\hline Epicatechin gallate & Epicatechin gallate_opt_C66_LP4 & $\begin{array}{l}\text { VDW: His48A, Ala55A, Cys57A, Thr58A, Ser59A, } \\
\text { His63A, His120A, Thr137A, Ala140A, Gly141A, } \\
\text { Arg143A, Lys122E, Ala123E, } \\
\text { HYI: Thr58A } \\
\text { CI: N/A } \\
\text { HB: Gly141A, Arg143A } \\
\text { AI: His120A }\end{array}$ & -61.67 \\
\hline $\begin{array}{l}\text { Epigallocatechin } \\
\text { gallate }\end{array}$ & Epigallocatechin gallate_opt_C48_LP5 & $\begin{array}{l}\text { VDW: His48A, Thr58A, His63A,His120A, Thr137A, } \\
\text { Asn139A, Ala140A, Gly141A, Ser142A, Arg143A, } \\
\text { Glu40E, Ala123E } \\
\text { HYI: N/A } \\
\text { CI: N/A } \\
\text { HB: Thr58A (Strong), Ala140A, Gly141A, Arg143A } \\
\text { AI: His120A }\end{array}$ & -60.24 \\
\hline
\end{tabular}

VDW: VanderWaal's interactions; HYI: Hydrophobic interactions; CI: Charge interactions; HB: Hydrogen bonding; AI: Aromatic interactions; N/A: Not available 
Indo Global Journal of Pharmaceutical Sciences, 2015; 5(3): 171-191

Table 10 Docking studies of tea polyphenols with protein 3KIJ (Glutathione Peroxidase of Homo sapiens).

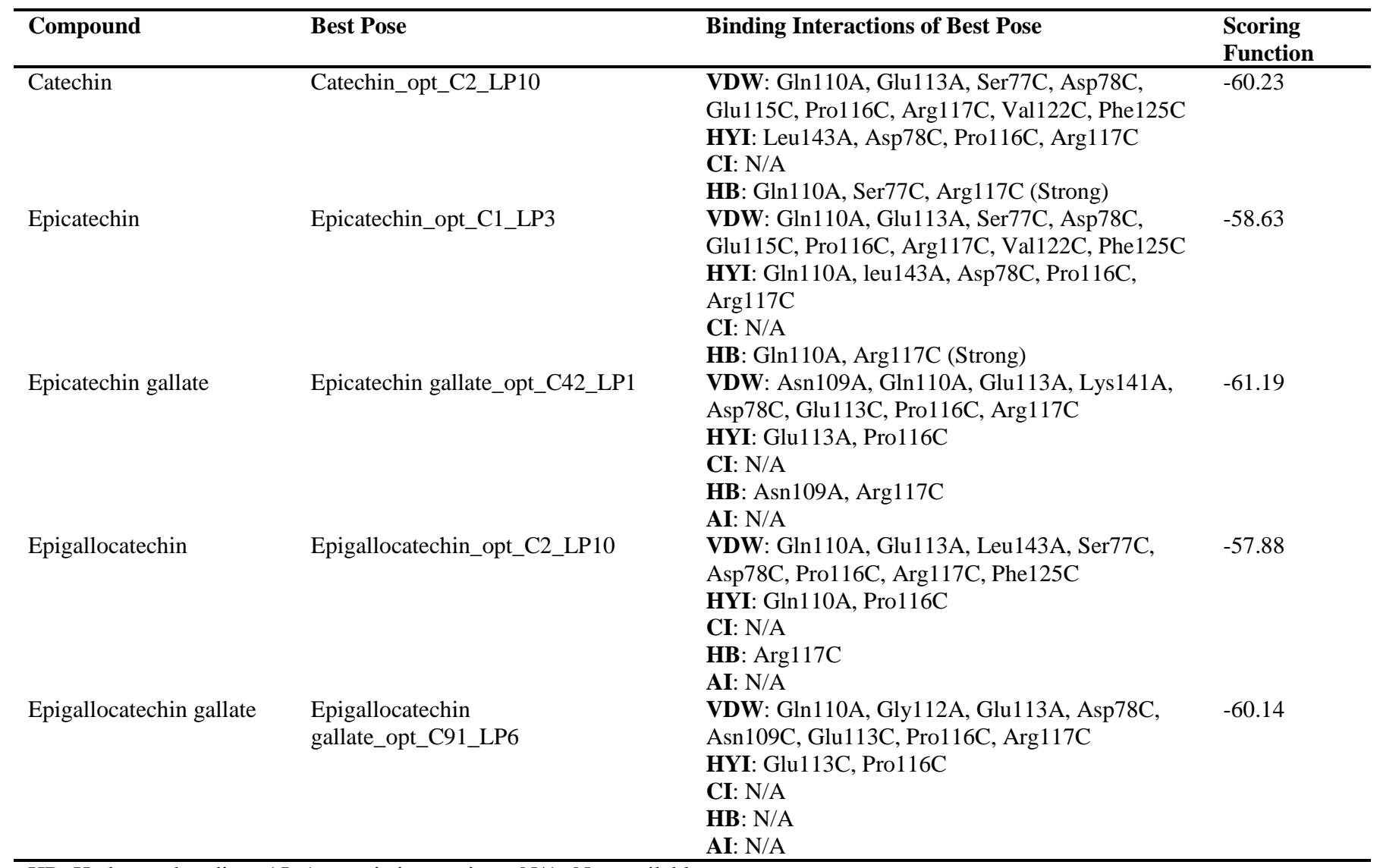

HB: Hydrogen bonding; AI: Aromatic interactions; N/A: Not available

Table 11 Docking studies of tea polyphenols with protein 1DGB (Erthyrocyte catalase of Homo sapiens)

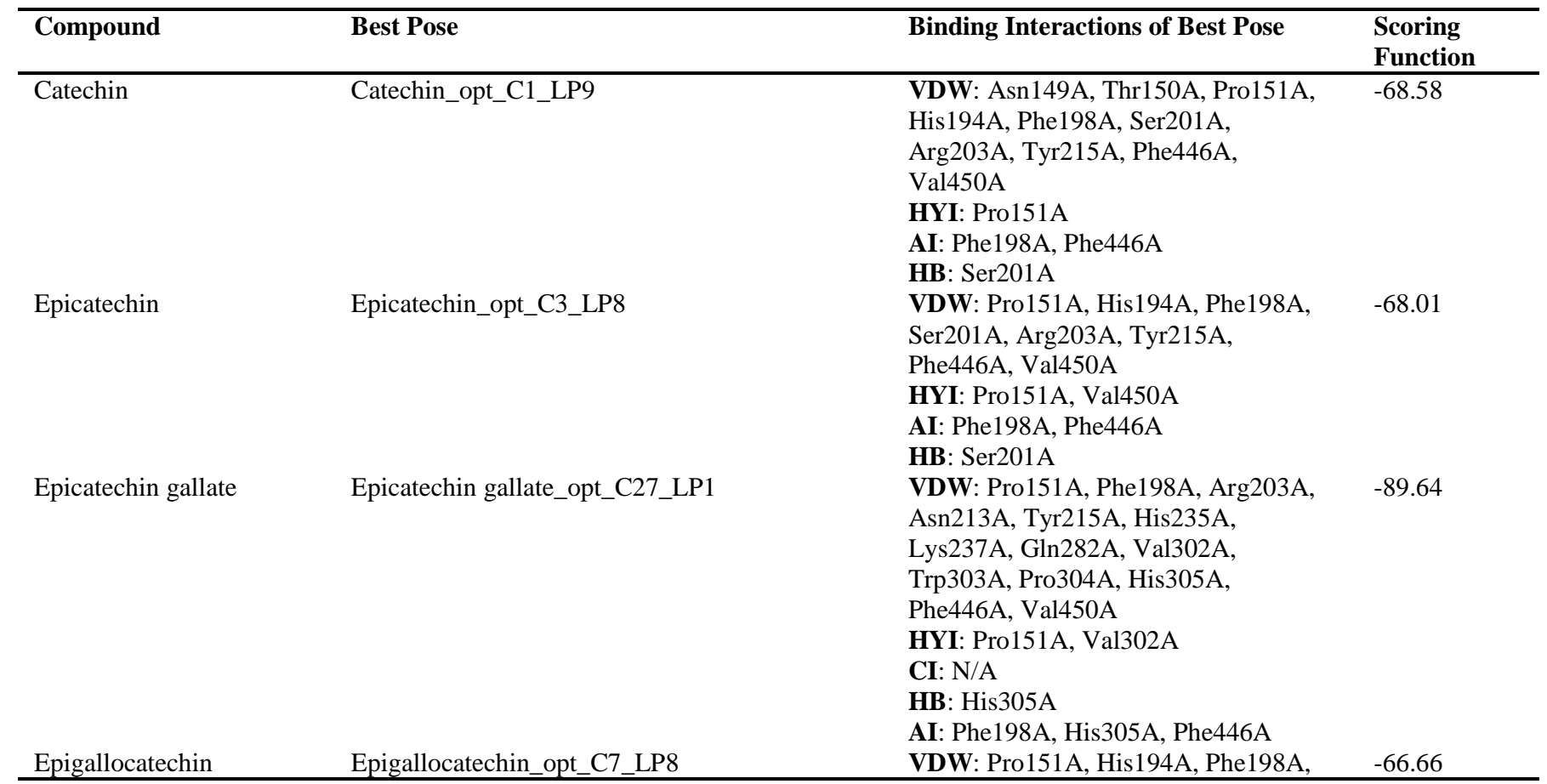




\begin{tabular}{|c|c|c|c|}
\hline Epigallocatechin gallate & Epigallocatechin gallate_opt_C9_LP7 & $\begin{array}{l}\text { Ser201A, Arg203A, Tyr215A, } \\
\text { Val302A, His305A, Phe446A, Val450A } \\
\text { HYI: Pro151A, Val450A } \\
\text { CI: N/A } \\
\text { HB: His194A, Ser201A, Tyr215A } \\
\text { AI: Phe198A (Strong), Phe446A } \\
\text { VDW: Pro151A, Phe198A, Arg203A, } \\
\text { Tyr215A, His235A, Gln282A, } \\
\text { Val302A, Trp303A, Pro304A, His305A, } \\
\text { Phe446A, Val450A } \\
\text { HYI: Pro151A, Val302A, Val450A } \\
\text { CI: N/A } \\
\text { HB: Gln282A, Trp303A, His305A } \\
\text { AI: Phe198A, His305A (Strong) }\end{array}$ & -86.79 \\
\hline
\end{tabular}

Table 12: Percent Inhibitory effect of black tea (CTC) on anticholinesterase enzyme

\begin{tabular}{|c|c|c|c|}
\hline \multicolumn{4}{|c|}{ \% Inhibition of AChE by Different Black Tea (CTC) extract } \\
\hline \multicolumn{2}{|c|}{$\mathrm{IC}_{50}=34.18 \mu \mathrm{g} / \mathrm{ml}$} & $\mathrm{IC}_{50}=34.97 \mu \mathrm{g} / \mathrm{ml}$ & $\mathrm{IC}_{50}=37.31 \mu \mathrm{g} / \mathrm{ml}$ \\
\hline $\begin{array}{l}\text { Concentration } \\
(\mu \mathrm{g} / \mathrm{ml})\end{array}$ & $\begin{array}{l}\% \text { of AChE Inhibition TV } 25 \\
\text { Variety }\end{array}$ & $\begin{array}{l}\text { \% of AChE Inhibition } \\
\text { TV } 26 \text { Variety }\end{array}$ & $\begin{array}{l}\% \text { of AChE Inhibition TV } 23 \\
\text { Variety }\end{array}$ \\
\hline 50.1 & 74.3 & 72.8 & 68.1 \\
\hline 40.2 & 56.7 & 55.2 & 50.1 \\
\hline 30.1 & 41.4 & 41.2 & 38.6 \\
\hline 20.1 & 32.3 & 31.4 & 30.2 \\
\hline 10.2 & 18.1 & 17.9 & 17.4 \\
\hline 5.0 & 12.5 & 12.6 & 12.5 \\
\hline
\end{tabular}
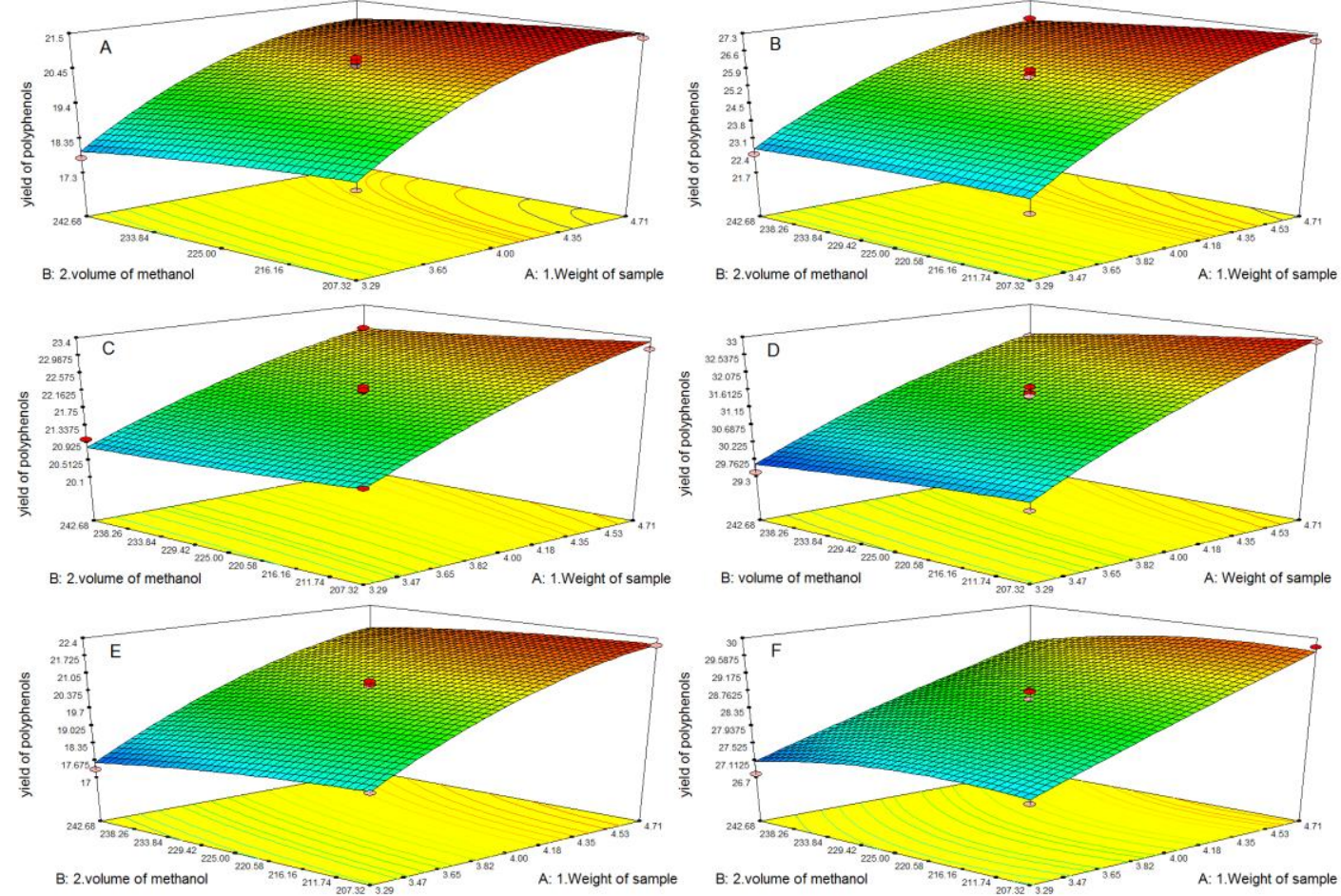

Figure4. RSM generated 3D-surface plots for the aqueous and methanolic extracts of TV varieties of tea. 
Indo Global Journal of Pharmaceutical Sciences, 2015; 5(3): 171-191

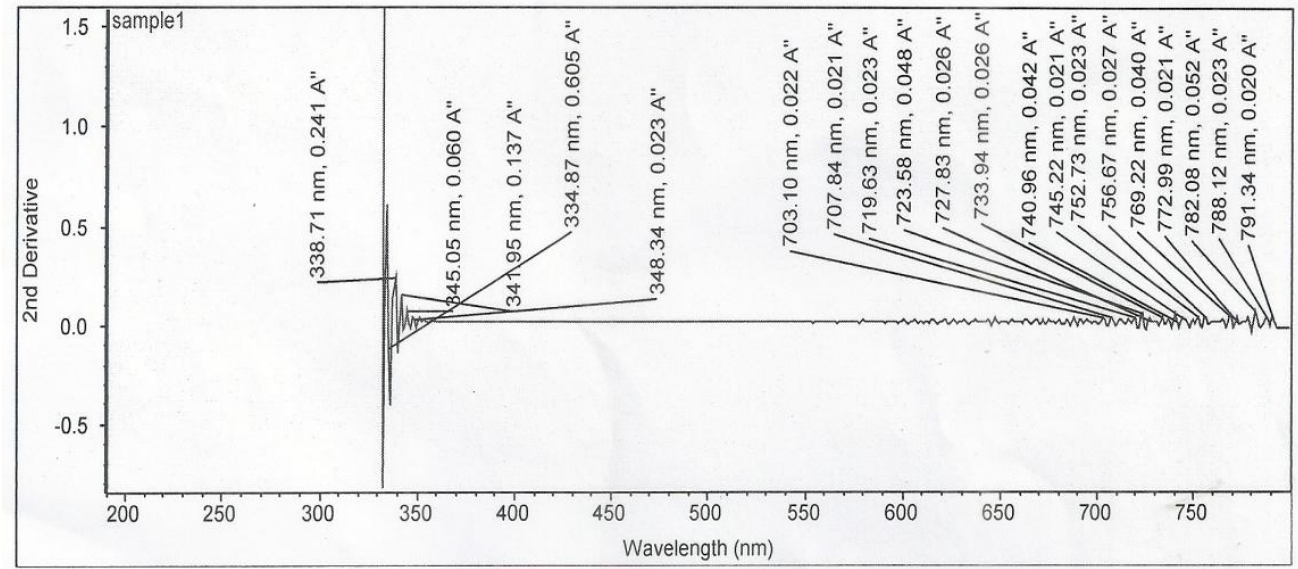

A

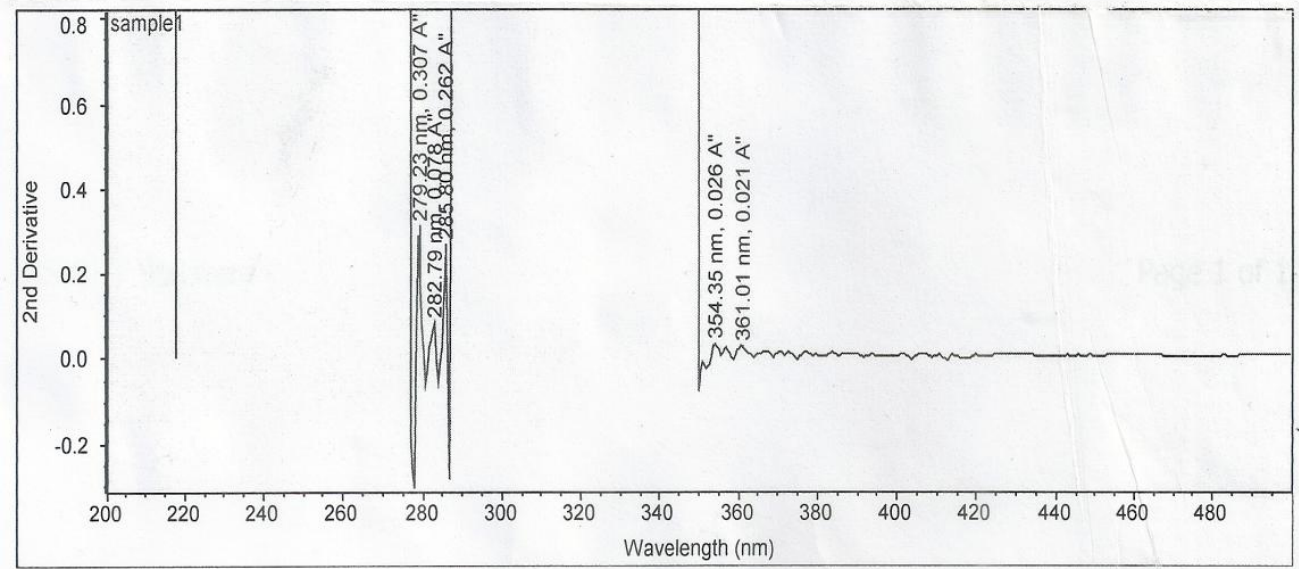

B

Figure 5. UV scanned graphs showing presence of (A) polyphenols and (B) flavonoids in fresh tea leaves of TV 25 variety.

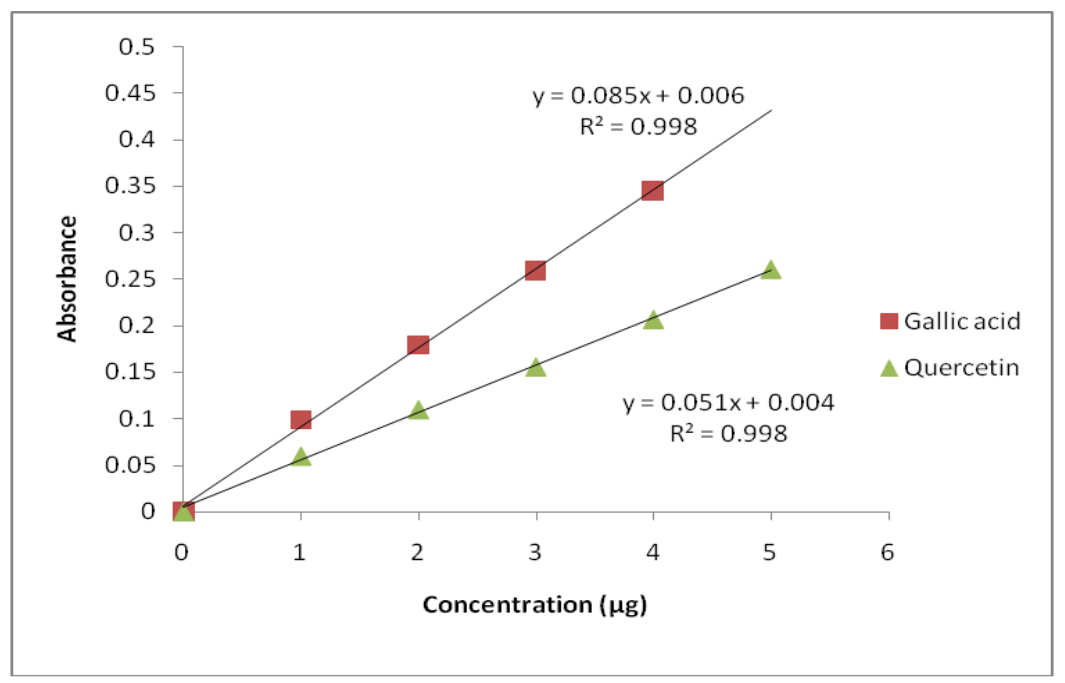

Figure 6. Calibration curves of gallic acid and quercetin 
Indo Global Journal of Pharmaceutical Sciences, 2015; 5(3): 171-191

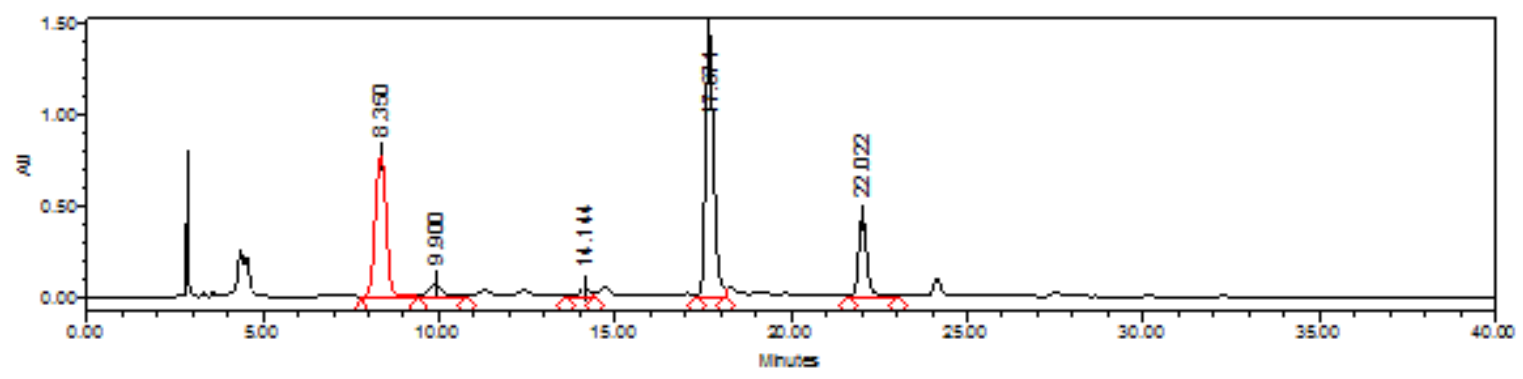

a

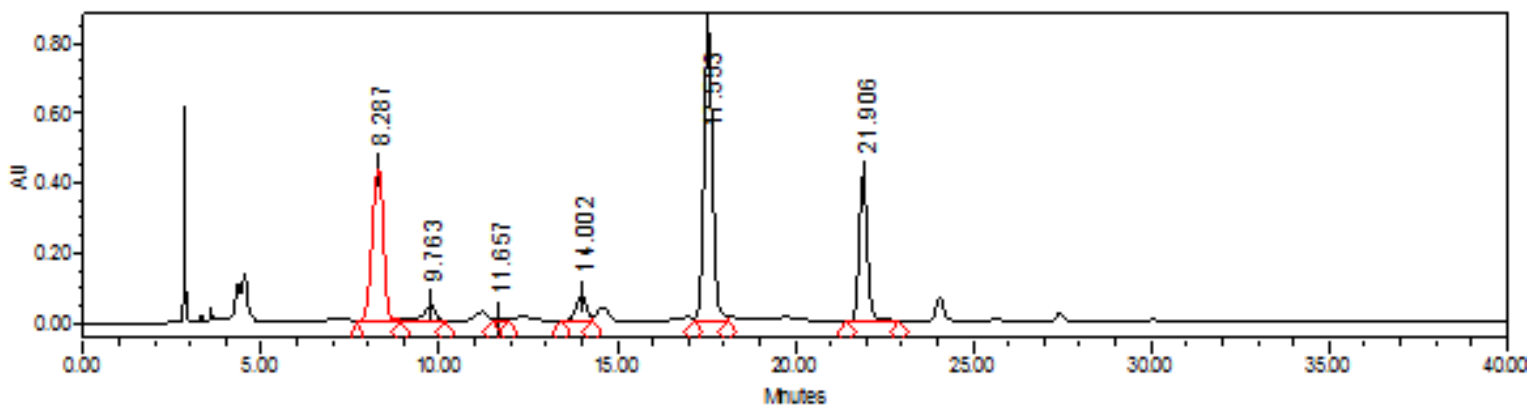

$\mathrm{b}$

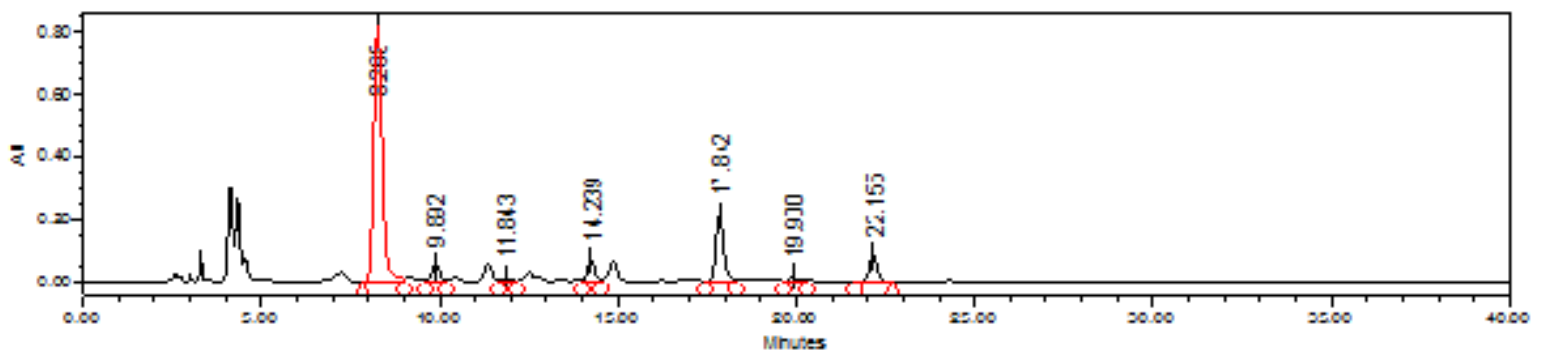

C

Figure 7. HPLC chromatograms of tea catechins of TV25 variety

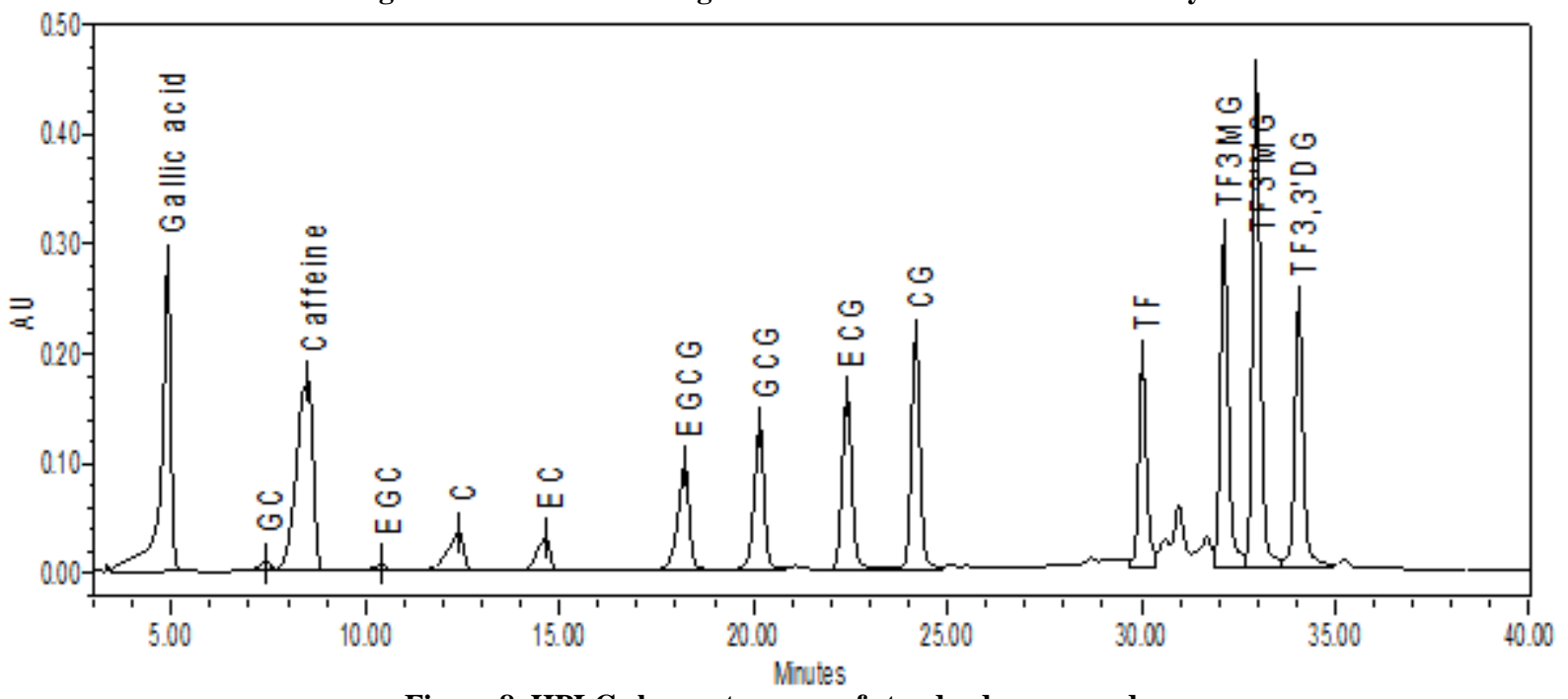

Figure 8. HPLC chromatograms of standard compounds 
Indo Global Journal of Pharmaceutical Sciences, 2015; 5(3): 171-191

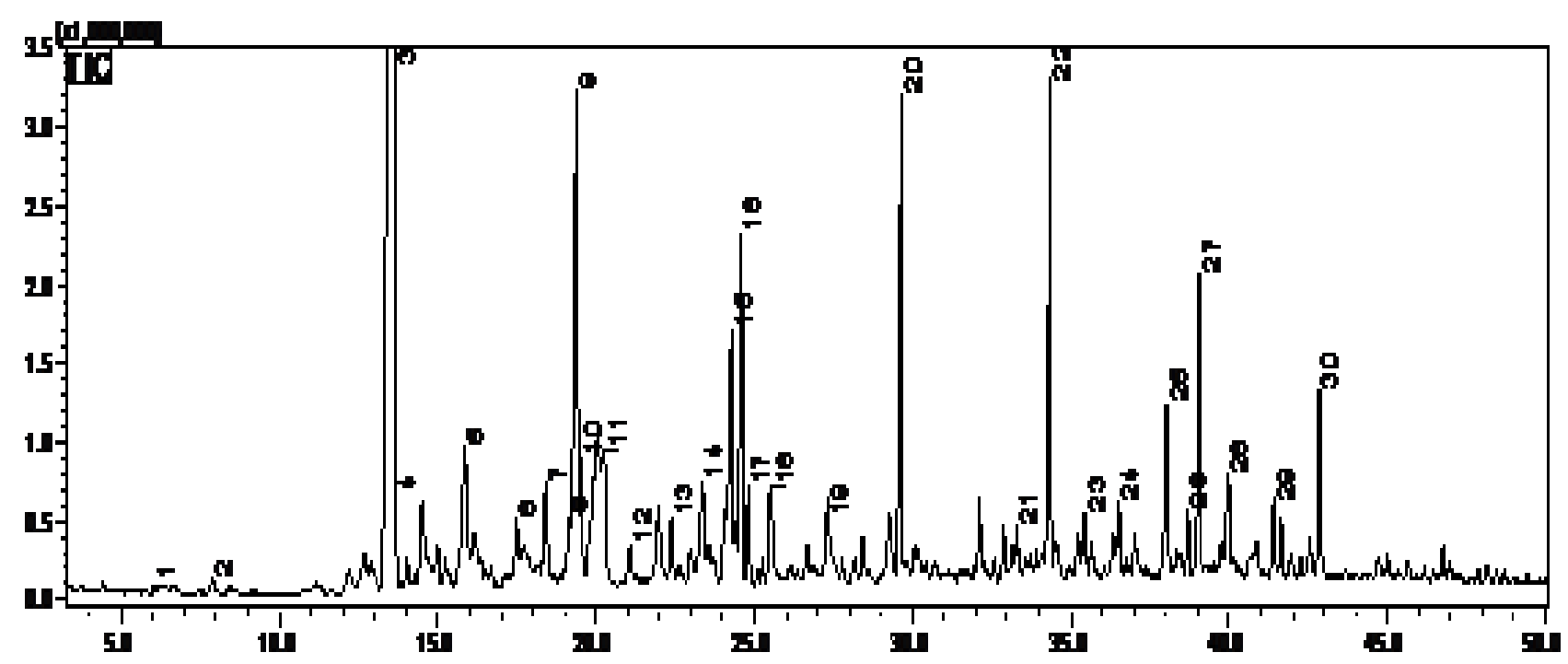

Figure 9. GC-MS chromatogram of volatile flavor compounds in made tea (CTC) of TV25 variety
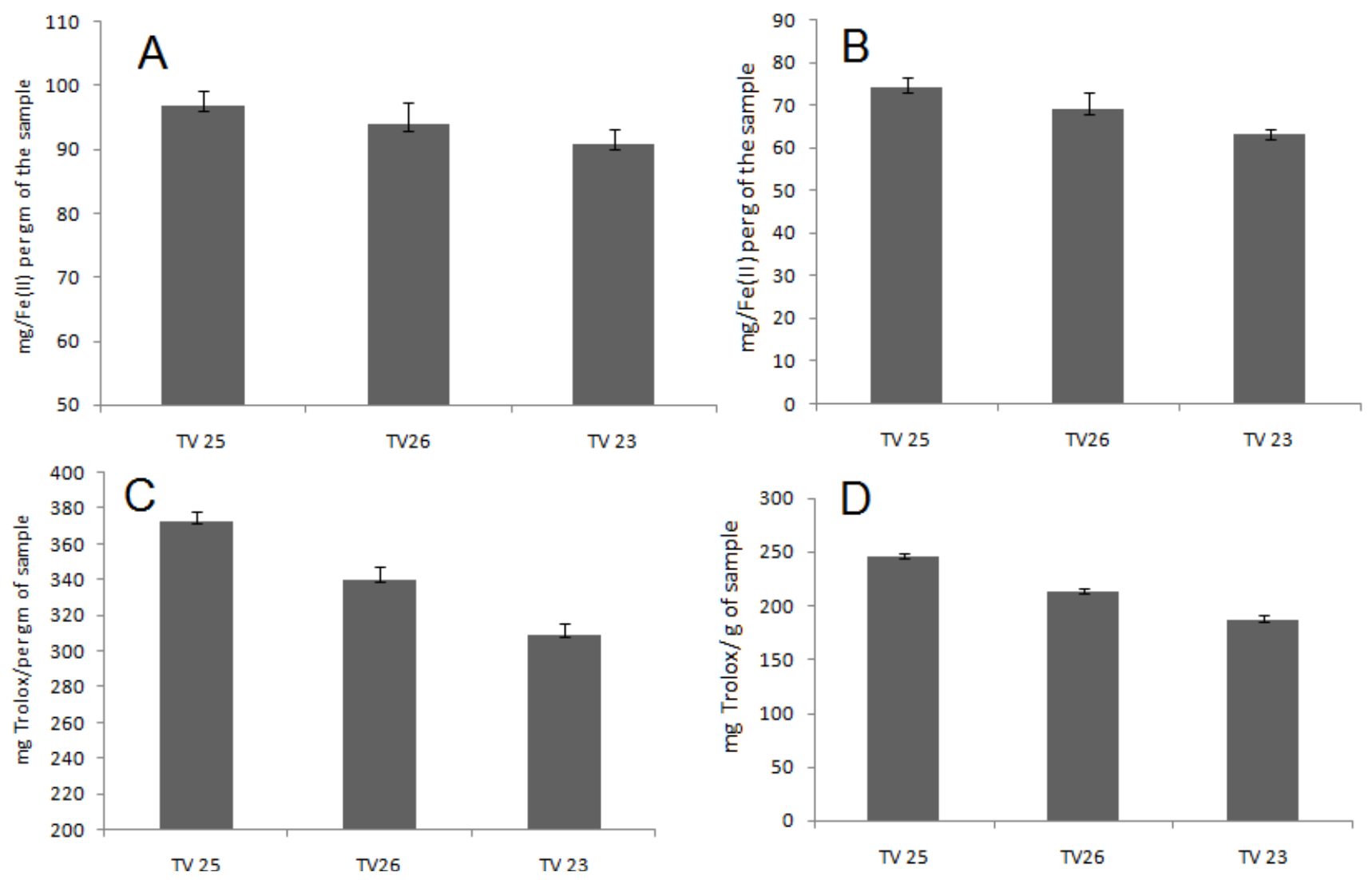

Figure 10. Comparative histogram of FRAP assay (A-B) and ABTS assay (C-D) for fresh tea leaves 
Indo Global Journal of Pharmaceutical Sciences, 2015; 5(3): 171-191

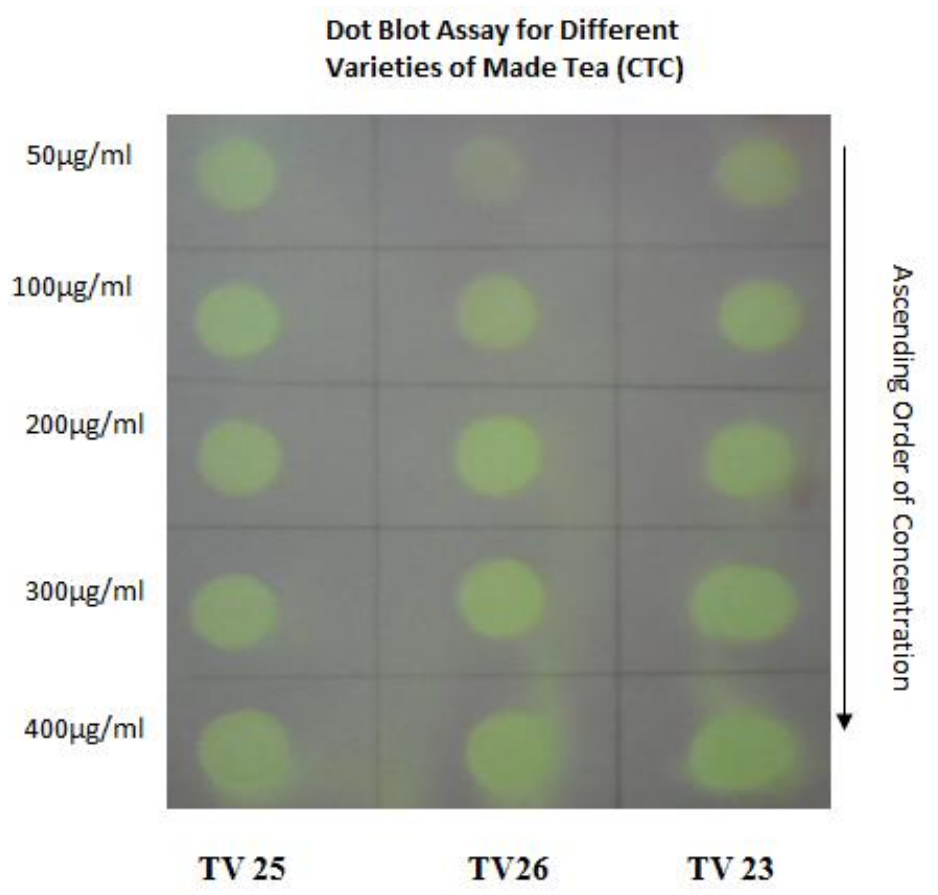

Figure 11. TLC plates for Dot blot assay of made tea (CTC) extracts

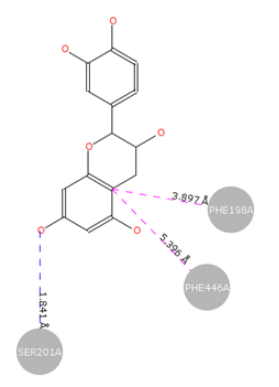

A

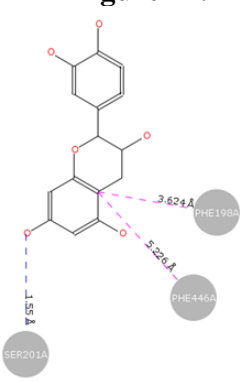

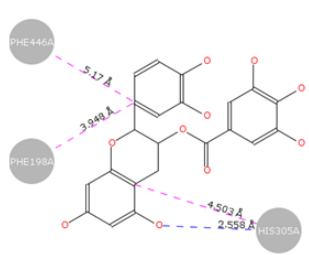

C

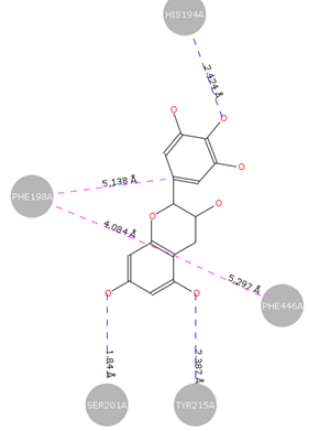

D

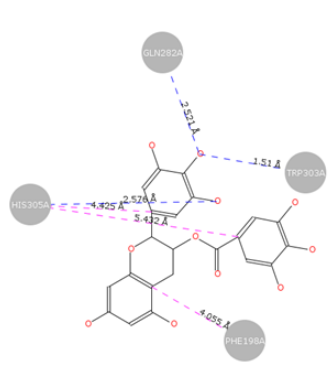

E

Figure12. Aromatic interactions and hydrogen bonding of (A) catechin, (B) epicatechin, (C) epicatechin gallate, (D) epigallocatechin and $(\mathrm{E})$ epigallocatechin gallate with erythrocyte catalase

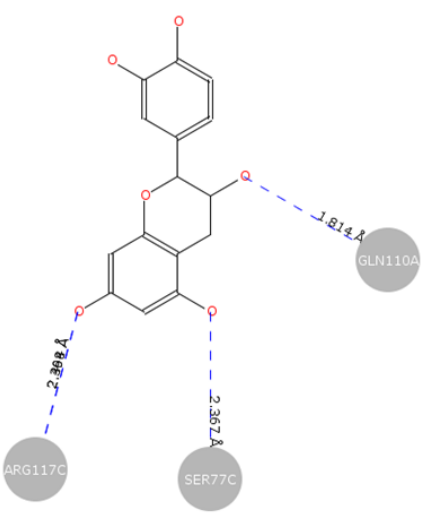

A

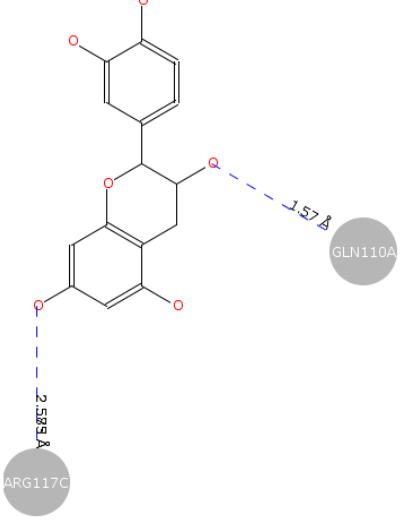

B

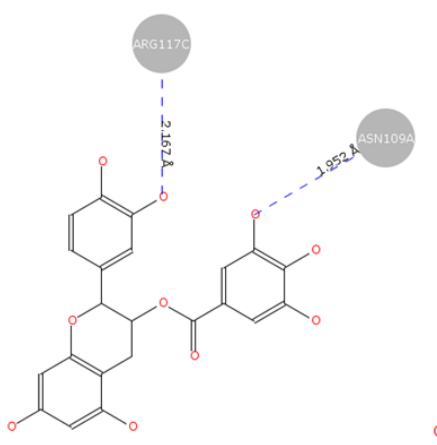

C

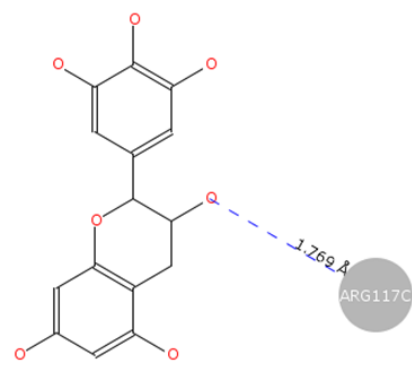

D

Figure13. Hydrogen bonding of (A) catechin, (B) epicatechin, (C) epicatechin gallate and (D) epigallocatechin with glutathione peroxidase 
Indo Global Journal of Pharmaceutical Sciences, 2015; 5(3): 171-191

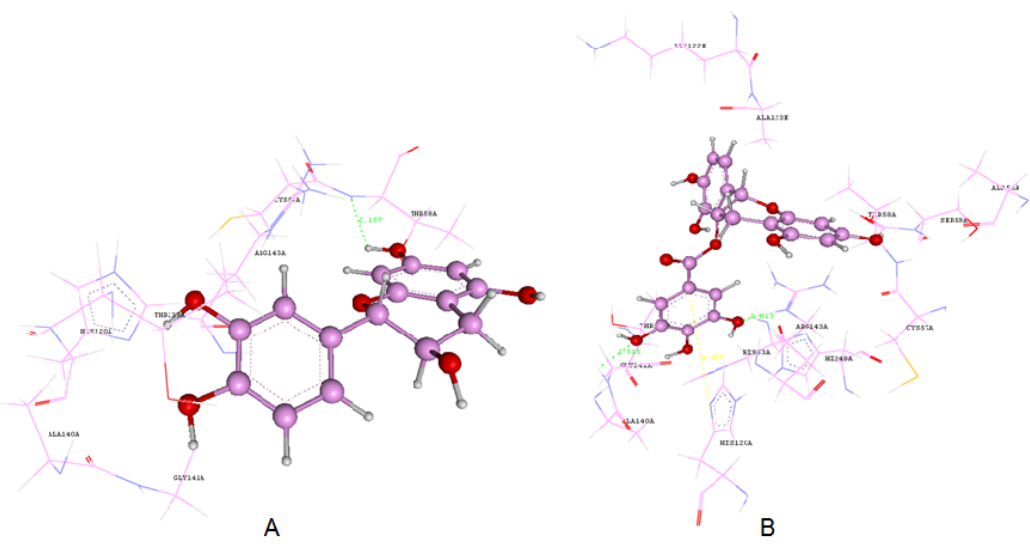

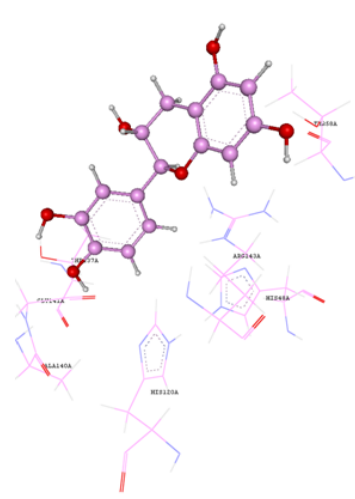

C

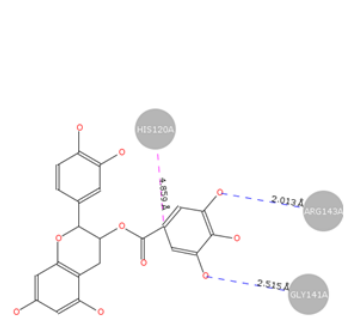

D

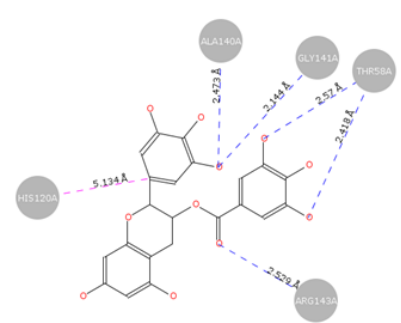

E

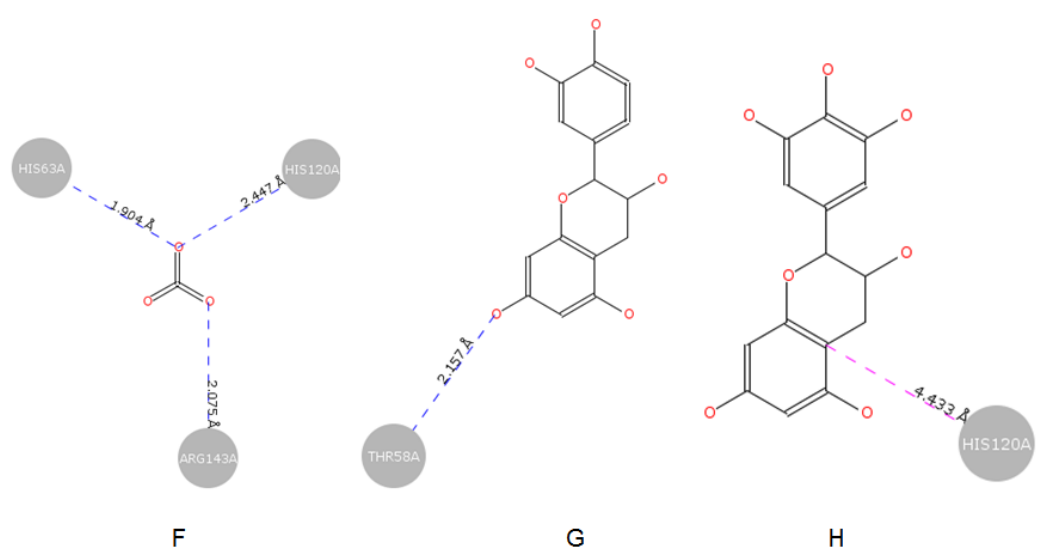

Figure 14. (A) Catechin, (B) epicatechin gallate and (C) epicatechin with superoxide dismutase; Hydrogen bonding and aromatic interactions of (D) epicatechin gallate, $(\mathrm{E})$ epigallocatechin gallate, $(\mathrm{F})$ bicarbonate ion and $(\mathrm{G})$ catechin and $(\mathrm{H})$ epigallocatechin with superoxide dismutase.

During extraction procedure, solvent selection is a crucial parameter so as to achieve maximal yield of bio-actives. Polar solvents such as water, ethanol, methanol, hydro alcohol and acetone were used for extraction of poly phenols. Literature surveys have shown that absolute acetone, N, N-dimethylformamide (DMF), ethanol, methanol and their $50 \%$ aqueous solutions are mostly used for black tea extractions and they gave appreciable yield of total polyphenolics. Aqueous acetone and DMF showed higher efficiency and absolute acetone showed lowest efficiency. Solvents like ethyl acetate being less polar gives low extraction yield and those with higher polarity like ethanol and methanol or their hydro alcoholic solutions will give higher extraction yields [34-37]. Many researchers preferred solvent mixtures rather than single solvents for extraction of poly phenols. The reason behind 


\section{Indo Global Journal of Pharmaceutical Sciences, 2015; 5(3): 171-191}

this is that the total phenolics are a mixture of different classes of phenols which are selectively soluble in the solvents. Hydroalcoholic solvents are best solvents for the extraction of phenolic compounds [34-37]. The chemistry behind it is that alcohol-water mixture offers the advantage of modulating the polarity of alcohol solvents and the solubility of poly phenols largely depends on the presence and number of hydroxyl groups, the molecular size and length of hydrocarbon. When water alone is used as the solvent only the water soluble bioactive components get extracted but there are many other components which may be soluble in the organic counterparts. Another fact to be considered is that there is a balance between polarity and polyphenolics extraction yield. In the current research, $80 \%$ methanol gave highest yield of poly phenolics both in fresh leaf and in made tea (CTC Black tea) but the solvent system not being fit for daily human consumptions, aqueous extracts will be considered where concentrations of tea poly phenols have also been found to be appreciable.

Major compounds detected by HPLC include epi-gallo catechin gallate, epi catechin gallate, epi gallo catechin and gallic acid in all three varieties. Concentration of these bio-actives was found to be maximum in TV 25 variety followed by TV 26 and TV 23. In all three extracts methanolic extracts showed higher concentration of bioactives than the aqueous extracts. The same fact is reflected in GC-MS analysis which showed the presence of about 30 volatile components amongst which linalool was maximum followed by tetradecane, tridecane and methyl salicylate (Table 7 and Fig.9).

Considering the results of in vitro antioxidant assays of fresh leaf and made tea like DPPH radical scavenging assay (Table 8), FRAP and ABTS assay (Fig.10) it was found that anti-oxidative potential of TV 25 variety (both fresh leaf or made tea) is maximum followed by TV 26 and TV 23. The same fact is further supported by dot blot assays showing rapid DPPH scavenging (Fig.11). In dot blot assays the increase in scavenging capacities of the extract along with ascending concentrations are clearly presented.

Basing on the results of in silico docking studies (Table 9-11 and Fig.12 (a-e); Fig. 13 (a-d); Fig. 14 (a-h)) it was found that all the molecules, viz. catechin, epicatechin, epicatechin gallate, epigallocatechin and epigallocatechin gallate were having strong affinity towards copper-zinc superoxide dismutase (4B3E), glutathione peroxidase $(3 \mathrm{KIJ})$ and erythrocyte catalase (1DGB). However epicatechin gallate with highest affinity towards all proteins was found to be most active in comparison to other bioactives. Here it is to be mentioned that the homeostatic condition of the body which is disturbed due to oxidative stress and the situation is counteracted due to elevated SOD level. But in due course SOD level depletes and if potent antioxidant bioactives like EGCG etc present in tea be applied at this stage its helpful to combat the crisis in a more effective manner. However further research works awaited.

\section{CONCLUSION}

Amongst the three tea varieties (TV 25, TV 26 and TV 23) grown in the non-traditional tea zone of IIT Kharagpur, both fresh leaves and made tea (CTC) of TV 25 variety showed evidence base results of maximal tea polyphenol yields with highest antioxidant potential proved in all in vitro assays and in silico molecular docking studies. Thus the varieties were found to be comparable to the traditional Assam clones with respect to polyphenol content and anti-oxidant potentials. Considering the significant polyphenol content and antioxidant capacity it can be concluded that these tea polyphenols can serve as value added dietary adjuvants and serve as effective natural therapeutic bullets in treating Alzheimer. However further extensive researches are warranted in this matter.

\section{ACKNOWLEDGEMENTS}

The fund for carrying out the current research has been provided by National Research Tea Board (NTRF) sponsored TAD project at IIT Kharagpur. The sponsor is deeply acknowledged.

\section{CONFLICT OF INTEREST}

Authors declare that the conflict of interest is nil.

\section{REFERENCES}

1. Saud, A., Rai, M.A., Muhammad, N., Muhammad, U.S., Furukh, F. Antioxidant potential of black tea (Camellia Sinensis L.)-A review. Pak J Food Sci., 2012; 22 (3): 128-132.

2. Shalini, D., Sudha, G. Antioxidative activity of various tea extracts (Camellia sinensis). J Biosci. Res., 2010; 1(1): 271-278.

3. Akande, I.S., Samuel, T.A., Agbazue, U., Olowolagba, B.L. Comparative proximate analysis of ethanolic and 


\section{Indo Global Journal of Pharmaceutical Sciences, 2015; 5(3): 171-191}

water extacts of Cvmbopgon citrtus (Lemon Grass) and four tea brands. J Pharma. Biomed. Sci., 2012; 22(03): 1-7.

4. Mitra, A., Dey, B. Therapeutic interventions in Alzheimer Disease. Neurodegenerative Diseases. In Tech Open Access, 2013: 291-317.

5. Ray, S., De, B. Acetylcholinesterase Inhibitory Properties of Black Tea and its polyphenolic components. Int. J Pharm. Pharma. Sci., 2012; 4(3): 334-337.

6. Kaur, T., Pathak, C.M., Pandhi, P., Khanduja, K.L. Effects of green tea extract on learning, memory, behavior and acetylcholinesterase activity in young and old male rats. Brain and Cog., 2008; 67: 25-30.

7. Sbbasian, S., Kairimi, F., Moghaddam, G., Soroush, A., Moloudian, H., Sadat, M. Antioxidant properties of different black tea samples and some Iranian native plants. Pharmacie Globale, 2013; 4(2): 1.

8. Lzzreen, N.Q.M.N., Fadzelly. M.A.B. Phytochemicals and antioxidant properties of different parts of Camellia sinesis leaves from Sabah tea plantation in Sabah, Malaysia. Int. J Food Sci., 2013; 20(1): 307312.

9. Turkmen, N., Velioglu, Y.S., Sari, F., Polat, G. Effect of extraction conditions on measured total polyphenol contents and antioxidant and antibacterial activities of black tea. Molecules, 2007; 12: 484-496.

10. Zhang, X., Lu, X., Li, S., Zhong, M., Shi, X., Luo, G. Investigation of 2,4-dichlorophenoxyacetic acid adsorption onto MIEX resin: Optimization using response surface methodology. J Taiwan Inst Chem Eng., 2014; 45: 1835-1841.

11. Bharath, E.N., Manjula, S.N., Vijaychand, A. In silico drug design tool for overcoming the innovation deficit in the drug discovery process. J Pharma. Biomed. Sci., 2011; 3(2): 8-12.

12. Singla, R.K., Bhat, V.G. QSAR model for predicting the fungicidal action of 1,2, 4-triazole derivatives against Candida albicans. J Enzyme. Inhib. Med. Chem., 2010; 25(5): 696-701.

13. Singla, R.K., Bhat, V.G., Kumar, T.N.V.G. 3Dquantitative structure activity relationship: a strategic approach for in silico prediction of anti-candididal action of 1, 2, 4-triazole derivatives. Indo Global $\mathbf{J}$ Pharm. Sci., 2013; 3(1): 52-57.

14. Malleshappa, N.N., Patel, H.M. A comparative QSAR analysis and molecular docking studies of quinazoline derivatives as tyrosine kinase (EGFR) inhibitors: A rationale approach to anticancer drug design. J Saudi Chem. Soc., 2013; 17(4): 361-379.

15. Igoli, J.O., Gray, A.I., Clements, C.J., Kantheti, P., Singla, R.K. Antitrypanosomal activity \& docking studies of isolated constituents from the lichen cetraria islandica: possibly multifunctional scaffolds. Curr. Top. Med. Chem., 2014; 14: 1014-1021.

16. Igoli, N.P., Clements, C.J., Singla, R.K., Igoli, J.O., Uche, N., Gray, A.I. Antitrypanosomal activity \& docking studies of components of crateva adansonii DC leaves: novel multifunctional scaffolds. Curr. Top. Med. Chem., 2014; 14: 981-990.

17. Singla, R.K., Paul, P., Nayak, P.G., Bhat, V.G. Investigation of anthramycin analogs induced cell death in MCF-7 breast cancer cells. Indo Global J Pharm. Sci., 2012; 2(4): 383-389.

18. Tshivhandekano, I., Mudau, F.N., Soundy, P., Ngezimana, W. Effect of cultural practices and environmental conditions on yield and quality of herbal plants: Prospects leading to research on influence of nitrogen fertilization, planting density and eco-physiological parameters on yield and quality of field grown bush tea (Athrixia phylicoides DC). J Med. Plant. Res., 2013; 7(34): 2489-2493.

19. Othman, A., Ismail, A., Abdul, G, N., Adenan, I. Antioxidant capacity and phenolic content of cocoa beans. Food Chem., 2007; 100: 1523-1530.

20. Modnicki, D., Balcerek, M. Estimation of total phenol contents in Ocimum basilicum L., Origanum vulgare L., Thymus vulgaris L., commercial samples. Herba. Polonica., 2009; 55(1): 35-42.

21. Mohammed, M.I., Sulaiman, M.A. Proximate, Caffeine and Tannin analyses in some brands of tea consumed in Kano Metropolis, Nigeria. Bayero J Pure Appl. Sci., 2009; 2(2): 19-21.

22. Khoddami, A., Wilkes, M.A., Roberts, T.H. Techniques for analysis of plant phenolic compounds. Molecules, 2013; 18: 2328-2375.

23. Atanassova, M., Georgieva, S., Ivancheva, K. Total phenolic and total favonoid contents, antioxidant capacity and biological contaminants in medicinal herbs. J Univ. Chem. Technol. Metal., 2011; 46(1): 81-88.

24. Shivaprasad, H.N., Khanam, S. HPLC analysis of polyphenols in green tea extracts. Asian J Chem., 2006; 18(2): 877-881.

25. Mandal, M., Samanta, T., Nelson, V.K., Bhandari, K., Mitra, A., Ghosh, B.C., Sen, G., Biswas, T. Protective effect of tea against copper $(\mathrm{Cu})$ toxicity in erythrocytes. Int. J Tea Sci., 2013; 9 (SI 2-3): 12-25.

26. Banu, S.S., Majula, A.S., Latha, M.T., Ravi, T.K. De Novo drug design and synthesis of certain Indole derivatives and screening for their Xanthine oxidase inhibitory activity. Int. J PharmTech Res., 2010; 2(4): 2128-2138

27. Shonisani, N. Effect of brewing temperature and duration on quality of black tea (Camellia sinensis) and equal combination of bush tea (Athrixia phylicoides DC) and black tea. Mini Dissertation, University of Limpopo, 2010.

28. Taheri, M., Sairi, R., Giahi, M., Ghafoori, H. Screening antioxidant activity of extracts from different tea samples. PharmacologyOnline, 2011; 2: 674-683.

29. Xu, J.Z., Yeung, S.Y.V., Chang, Q., Huang, Y., Chen, Z.Y. Comparison of antioxidant activity and bioavailability of tea epicatechins with their epimers. J of Nutri., 2004; 91: 873-881.

30. Patel, G., Gauni, B., Mehta, K., Patel, B.N. Comparative study of antioxidant capacity of raw powder and waste black tea by FRAP assay. Res. J Recent Sci., 2014; 3: 42-44.

31. Selvam, K., Rajinikanth, R., Govarthannan, M., Paul, A., Selvankumar, T., Sengottaiyan, A. Antioxidant potential and secondary metabolites in Ocimum sanctum L.at various habits. J Med. Plant Res., 2013; 7(12): 706-712. 


\section{Indo Global Journal of Pharmaceutical Sciences, 2015; 5(3): 171-191}

32. VLifeMDS: Molecular Design Suite, VLife Sciences Technologies Pvt. Ltd., Pune, India, 2013 (www.vlifesciences.com)

33. Mukherjee, P.K., Kumar, V., Mal, M., Houghton, P.J. Acetylcholinesterase inhibitors from plants. Phytomed., 2007; 14: 289-300.

34. Franco, D., Sineiro, J., Rubilar, M., Sanchez, M., Jerez, M., Pinelo, M., Costoya, N., Nunez, M.J. Polyphenols from plant materials: extraction and antioxidant power. Elect. J Environ. Agri. Food Chem., 2008; 7(8): 3210-3216.

35. Tatiya, A.U., Tapadiya, G.G., Kotecha, S., Surana, S.J. Effect of solvents on total phenolics, antioxidant and antimicrobial properties of Bridelia retusa Spreng sem bark. Ind. J. Nat. Prod. Res., 2011; 2(4): 442-447.

36. Khedher, O., Moussaoui, Y., Salem, R.B. Solvent effects on phenolic contents and antioxidant activities of the Echinops Spinosus and the Limoniastrum Monopetalum. Res. J Pharm. Biol. Chem. Sci., 2014; 5(2): 66-76.

37. Mohammedi, Z. Impact of solvent extraction type on total polyphenols content and biological activity from Tamarix Aphylla (L.) Karst. Int. J Pharm. Biol. Sci., 2011; 2(1): 609-615.

Indo Global Journal of Pharmaceutical Sciences( ISSN 22491023 ; CODEN- IGJPAI; NLM ID: 101610675) indexed and abstracted in EMBASE(Elsevier), SCIRUS(Elsevier),CABI, CAB Abstracts, Chemical Abstract Services(CAS), American Chemical Society(ACS), Index Copernicus, EBSCO, DOAJ, Google Scholar and many more. For further details, visit 